\title{
Prawo i wolność. Studium filozofii politycznej Borysa Wyszesławcewa
}

I.

K iedy dwa tysiące lat temu sekta judeochrześcijańska wyłaniała się - $\mathrm{z}$ głównego nurtu religii Tory, zasadniczym motywem i podstawą owego wyodrębnienia było uznanie przez judeochrześcijan Jezusa za wcielenie oczekiwanego mesjasza przy całkowitej akceptacji dla zawartego w świętej księdze religii żydowskiej prawa ${ }^{1}$. Dopiero wystapienie Pawła z Tarsu z tezą o boskości Jezusa (i dogmatem „zmartwychwstania”) doprowadziło do radykalizacji nowego ruchu religijnego i uznania konieczności bardziej zdecydowanego odróżnienia się od religii Mojżesza. Znalazło to wyraz w odrzuceniu - bardziej radykalnym u Pawła, nieco stonowanym u „ewangelistów” - „starotestamentowego” Prawa; z uwagi na ostrość wyrażeń ${ }^{2}$, jakich do tego odrzucenia użył Paweł, a także na charakter zastosowanej argumentacji, uzasadnione wydaje się przypuszczenie, że mamy w tym wypadku do czynienia nie tylko z odrzuceniem prawa żydowskiego, ale i z zanegowaniem prawa jako medium komunikacji między niższym i wyższym (w tym i najwyższym) szczeblem hierarchii. Usunięcie prawa jako medium komunikacji społecznej nie tylko wpływa na charakter relacji w obrębie struktury hierarchicznej, ale, co ważniejsze, eliminuje samą możliwość niehierarchicznej struktury relacji społecznych i politycznych. Niektórzy spośród chrześcijan złagodzili z czasem swoje stanowisko względem prawa (zadowalając się prymatem religijnie definiowanego ,prawa naturalnego"), gdy tymczasem według innych, zwłaszcza według rosyjskich chrześcijan prawosławnych, w tym również niektórych

1 Tak np. H. Macoby; zob. H. Macoby, Kowal mitu. Święty Paweł i wynalazek chrześcijaństwa, Zgorzelec 2008, s. 137-139.

2 Choćby takiego: „Jeśli [...] pozwolicie się prowadzić duchowi, nie znajdziecie się w niewoli Prawa". Ga 5, 18. 
konserwatywnie zorientowanych rosyjskich myślicieli, to prawo jako takie jest złem - dokładnie tak, jak to przedstawił Paweł ${ }^{3}$.

Odrzucenie prawa żydowskiego można uznać za element przekształceń zachodzących w pewnego typu instytucji kulturowej, jaką jest religia, podczas gdy odrzucenie prawa jako takiego nabiera już bardziej uniwersalnego znaczenia ${ }^{4}$ - odnosi się do pewnego sposobu rozumienia ogólnokulturowego porządku i do samego tego porządku, niezależnie od tego, czy porządek ten miałby być co do swojej kulturowej formy religijnym, czy pozareligijnym porządkiem.

Nie można wykluczyć, że Pawłowi chodziło początkowo tylko o prawo żydowskie, że tylko żydowskie prawo było przedmiotem jego głębokiej niechęci ${ }^{5}$, i tylko z czasem niechęć do tej szczególnej formy zapośredniczenia relacji między absolutnym podmiotem ${ }^{6}$ i człowiekiem przekształciła się

3 Konserwatywną rosyjską myśl prawicową, wrogo nastawioną do prawa, ale także niechętną prawu myśl lewicową (skądinąd, wbrew pozorom, powodowanym posługiwaniem się językiem Oświecenia, również w dużej mierze konserwatywną) przedstawia w obszernym studium, wprowadzającym do jego książki o rosyjskiej liberalnej filozofii prawa, Andrzej Walicki. Zob. A. Walicki, Filozofia prawa rosyjskiego liberalizmu, Warszawa 1995, r. I: Tradycja krytyki prawa, s. 17-114. Autor ten o związkach ,tradycji krytyki prawa” z prawosławiem wspomina tylko mimochodem, i tylko pośrednio, odnotowując słowianofilską ideę soborowości, tym bardziej krytyki tej nie wiąże z chrześcijaństwem jako takim, koncentrując się raczej na wpływach niemieckich, związanych z wyodrębnieniem ,prawa typu Gemeinschaft” i ,prawa typu Gesellschaft”. Ma to zapewne związek z zawartą we Wstępie deklaracją, że „książka [...] jest rozprawą historyczną i nie pretenduje do rozstrzygania problemów teoretycznych". Ibidem, s. 15.

4 Uniwersalizmu dopatruje się u Pawła A. Badiou (zob. A. Badiou, Święty Paweł. Ustanowienie uniwersalizmu, Kraków 2007, s. 83-84), zdaje się jednak, że nie chodzi mu o „uniwersalne znaczenie”, lecz o jedną uniwersalną prawdę, która zresztą, jego zdaniem, nie musi mieć charakteru religijnego, z czym akurat trudno się nie zgodzić, przy czym nie tylko dlatego, że prawda rewolucyjna, jak zdaje się sądzić Badiou, ,,jest jedna”, ale dlatego, że Paweł w swym ekstremizmie przekracza umiarkowaną religijną postać apologii jednopodmiotowości. „Uniwersalny” jest ponadto Paweł w tym znaczeniu, w jakim uniwersalny jest problem prawa jako formy tego, co metafizyczne, podczas gdy problem prawa i łaski jedynie partykularny (tu: religijny).

5 W sprawie pawłowych idiosynkrazji, które w tym miejscu pomijam, podobnie jak całej freudowskiej analizy postaci, zob. M. Onfray, Traite d'atheologie, Paryż 2005, s. 165 i n.

6 Podmiotowość tego absolutu nie jest u Pawła taka pewna, przynajmniej według Badiou, który uporczywie twierdzi, że nawet nie wiary w boskość Chrystusa domagał się Paweł, a wiary w jego zmartwychwstanie. To wydaje się logiczne, tym bardziej, że w przeciwieństwie do podmiotowego absolutu (który w dodatku może wpaść na 
w niechęć do formy w ogóle, lub raczej w przekonanie (skądinąd jak najbardziej słuszne!), że forma umniejsza absolut, ujmuje mu absolutnego charakteru, uzależnia go od siebie. A może chodziło mu nie tyle o negację wszelkiej formy - nie sposób wykluczyć, że Paweł nie liczył na zniszczenie wszelkiej formy, ale raczej szukał takiej, która by najmniej uzależniała władzę absolutną czy to Boga, czy pochodzącą od Boga, od człowieka. Formy takiej - jedynej, jaka by mogła zapośredniczać relację człowieka i Władzy (powtórzmy: czy to Boga, czy pochodzącej od Boga) - doszukiwał się w miłości, mającej płynąć ku niej od człowieka, i w łasce, która ma (lub nie ma, jak to łaska ${ }^{7}$ ) spływać od niej ku człowiekowi ${ }^{8}$. Pisał wprawdzie w jednym ze swoich Listów, że ,całe Prawo wypełnia się w tym jednym nakazie: Będziesz miłował bliźniego swego jak siebie samego"," nie wydaje się jednak, by na tej zasadzie można było układać stosunki z Bogiem i z władzą w całości od niego pochodzącą ${ }^{10}$. Sam zresztą Paweł w to nie wierzył stwierdzając w kolejnym zdaniu, że „Jeśli jednak pozwolicie się prowadzić duchowi, nie znajdziecie się w niewoli Prawa" ${ }^{11}$. Trzeba się

pomysł podzielenia się swoją podmiotowością i tym samym swoim absolutnym charakterem - a o tym, że absolutny podmiot wpadł na taki pomysł, świadczy starotestamentowa idea przymierza), ,zmartwychwstanie” takim podmiotem być nie może. Absolutem nie jest u Pawła prawdopodobnie Bóg osobowy, ale sama relacja podstawowa, a ta, w sposób oczywisty, też nie może być podmiotem; stąd zasadność tezy Badiou, że znaczenie Pawła wykracza poza religię. Dodajmy - również dlatego, że pokazuje on, iż istota religii nie tkwi w samej religii.

${ }^{7}$ W sprawie różnych odcieni znaczeniowych teologicznego pojęcia „łaska” zob. np. M. Rode, Mała encyklopedia teologiczna, t. 1, s. 992.

8 A więc ostatecznie w prawie o strukturze podmiotowo-przedmiotowej (rozkazu i posłuszeństwa rozkazowi, skądinąd właściwej większości norm prawa żydowskiego), w przeciwieństwie do struktury podmiotowo-podmiotowej, do której odwołuje się biblijny archetyp przymierza oraz (już nie mitologiczna) koncepcja umowy społecznej.

${ }^{9}$ Ga 5,14 .

10 Znamienna jest $\mathrm{w}$ tym kontekście różnica między tym twierdzeniem (że w przykazaniu miłowania bliźniego wyczerpuje się całe prawo), a twierdzeniem z Mateusza $(22,37)$, że najważniejsze jest bezwarunkowe miłowanie Boga. Nie jest to przemilczenie, skoro Listy są wcześniejsze, a zatem tendencyjność tu opisana na ten aspekt sprawy się nie rozciagg. Inna rzecz, że można by twierdzenie Pawła o wyczerpywaniu się prawa miłowaniem bliźniego potraktować dosłownie, ale wtedy należałoby odrzucić pawłową interpretację przymierza jako obietnicy $(\mathrm{Ga} 4,23)$ i jego utożsamienie władzy z Bogiem, nie mówiąc o jego nihilizmie prawnym, a więc - samego Pawła, i zbudować zupełne inną metafizykę.

${ }^{11}$ Ga 5, 18. Badiou uważa, że Pawłowi chodziło jednak o ufundowanie nowego prawa na miłości, i nawet odwołuje się, przy jej definiowaniu, do wzajemności, ale 
oczywiście zgodzić z Pawłem, że nie jest dobrze znaleźć się „w niewoli prawa" ${ }^{\prime 2}$, nie tylko zresztą żydowskiego, ale jakiegokolwiek innego.

Wcześniej (a w religii żydowskiej po dziś dzień) na oznaczenie formy, zapośredniczającej relację między Bogiem i wiernym, między Władzą i poddanym, używano pojęcia prawa, skądinąd przez Boga i lud w s p ó 1 n i e ustanowionego. Co ma teraz tę relację zapośredniczać, co Paweł i jego wyznawcy nazywają miłością?

Tym czymś może być chyba tylko ,goła” siła ${ }^{13}$. Wiadomo jednak, że goła siła może być co najwyżej przejściową formą wspomnianej relacji. Może być więc raczej ideałem, wzorcem niż rzeczywistością. Ale jako ideał musi mieć bardziej pociagającą formę, a zarazem $\mathrm{m}$ a s $\mathrm{k} \mathrm{ę}{ }^{14}$; tą maskąjest „miłość”.

w twierdzeniu, że „w myśli Pawła miłość jest wiernością wobec wydarzenia Chrystusowego” nie dopatruje się żadnej sprzeczności z „miłowaniem bliźniego jak siebie samego". Jeśli istnieje tu przynajmniej ważna różnica, mielibyśmy ostatecznie to samo, co u Mateusza (Mt 22, 37): zasadę podstawową, skonstruowaną z miłości ,pierwszorzędnej” („wierność wobec wydarzenia Chrystusowego” itp.) oraz miłości, która ma regulować stosunki międzyludzkie. Badiou nie widzi również różnicy, tym bardziej, że szczególnie przemawia do niego teza o zapośredniczeniu wiary przez miłość. Jeśli tą zapośredniczającą wiarę miłością nie miałaby być miłość ,polityczna”, ale ta z przykazania miłowania bliźniego, wówczas „Chrystus” bliźniego by jedynie symbolizował, nie zaś władzę. Ale co wtedy zrobić z pochodzeniem władzy od Boga (a relacji z nią, poza szczególnym przypadkiem ludu - suwerena w demokracji, nie da się wtłoczyć w ramy „wzajemnej miłości”)? Zob. A. Badiou, Święty Paweł, op. cit., s. 96-98.

12 Chociaż, z drugiej strony, znalezienie się ,w niewoli” prawa miłowania bliźniego jak siebie samego należałoby uznać raczej za coś godnego pożądania, z tym tylko, że określenie „,w niewoli” trzeba by w tym wypadku traktować metaforycznie. Nowoczesnym odpowiednikiem takiego prawa jest prawo stanowione w trybie demokratycznym.

3 „Władza od początku wyklucza siłę”. Alexandre Kojeve, La notion d'autorite, Paris 2004. Cyt. za wydaniem rosyjskim A. Kożev, Poniatije vlasti, Moskwa 2007, s. 19. Przyznając rację filozofowi można tylko uściślić, że pod wszelką legitymizującą formą (bez której nie może być mowy o władzy, i w tym sensie „władza wyklucza siłę”) kryć się może albo przymierze, albo przewaga, czyli siła, co zresztą pozwala rozróżnić dwa typy prawa oraz dwa typy władzy: władzę par excellence (tę opartą na przewadze), i reprezentację, władzę z istoty ograniczoną (ograniczoną porozumieniem stron). Władzą par excellence byłaby tu suwerenność ludu, ta jednak nie jest oparta na przewadze, lecz na umowie. I jeszcze: ,goła siła” nie oznacza tu siły fizycznej, ale raczej groźbę jej użycia, a więc przemoc psychiczną.

$14 \mathrm{~W}$ sprawach zasadniczych i w momentach przełomowych siłę się demonstruje, na co dzień jednak lepiej ją maskować. Stąd tak wiele uwagi poświęca Paweł miłości, dbając zarazem o zacieranie różnic między dwoma jej rodzajami. Arcydziełem zacierania jest hymn (1 Kor 13, 1-13). Zarazem utożsamienie władzy z Bogiem (Rz 13, 1-2) nie pozostawia wątpliwości co do ścisłego związku ,władzy” i „miłości” u Pawła. 
Nie jest to zreszta, jak wiemy już ze Starego Testamentu, forma jedyna. Występują tam jeszcze przynajmniej dwie formy: jedna dosyć „prehistoryczna", to groźba ${ }^{15}$; druga znacznie bardziej cywilizacyjnie zaawansowana: to prawo ${ }^{16}$. Jeszcze prymitywne, proste ${ }^{17}$, ale jednak prawo: jest nim zakaz spożywania owoców z drzewa wiadomości złego i dobrego, zresztą również obwarowany nie zawoalowaną groźbą, podobnie jak później w dekalogach - groźbą śmierci ${ }^{18}$.

Można powiedzieć, że Stary Testament zna miłość tylko w dwóch postaciach - tej z przykazania miłowania bliźniego jak siebie samego ${ }^{19}$ oraz z Pieśni nad Pieśniami (abstrahuję tu od prób interpretowania jej w duchu ewangelii i Pawła). Miłość ,polityczna” (specyficzny stosunek do władzy „pochodzacej od Boga”) jest zatem wynalazkiem Pawła. Wiemy, że miłość (choćby z ,przykazania" ${ }^{20}$ miłowania bliźniego jak siebie samego), aby być miłością, musi być „równoważona” przez miłość, gdy tymczasem „miłość polityczna” równoważona jest przez (polityczną!) łaskę ${ }^{21}$.

Jeśli „,duchem”, któremu mamy dać się prowadzić, jest miłość, to zasadne jest pytanie, o który z dwóch rodzajów miłości chodzi w istocie Pawłowi, i jeśli, jak sądzę, chodzi mu o miłość, określoną tu jako ,polityczna”, w przeciwieństwie do miłości par excellence (w tym „miłości bliźniego"), to czy rzeczywiście najskuteczniej z "niewoli prawa” ta właśnie miłość ,wyzwala”? A jeśli tak, to kogo? Innymi słowy - jeśli przyjmiemy, że od prawa abstrahować można ostatecznie tylko w eksperymencie myślowym - czy orientacja na ten właśnie spośród możliwych

15 „Z wszelkiego drzewa tego ogrodu możesz spożywać według upodobania; ale z drzewa poznania dobra i zła nie wolno ci jeść, bo gdy z niego spożyjesz, niechybnie umrzesz", Rz 2, 16-17.

${ }^{16}$ Wypada wstępnie odnotować, że prawo występuje w Starym Testamencie nie tylko jako forma siły. Można nawet powiedzieć, że w tej postaci występuje tam ono tylko na samym początku, chociaż i tam (tam, gdzie Bóg wprowadza arbitralny zakaz) jego niezbywalnym warunkiem jest (choćby i nie dobrowolne) przyzwolenie adresata normy na to, by być traktowanym wyłącznie jako adresat.

${ }^{17}$ Prymitywne w swojej prostocie, ale zarazem genialne pod względem trafności ujęcie istoty prawa, które odnosi się do kompetencji (w tym wypadku wyłącznej kompetencji) w rozstrzyganiu co dobre i złe.

${ }^{18}$ Wj 20, 2-5; Pwt 5, 6-9.

19 Kpł 19, 18.

${ }^{20}$ Nie jest to właściwie przykazanie, czyli nakaz, ponieważ każda ze stron relacji miłowania („,bliźniego jak siebie samego") jest zarazem nadawcą i adresatem normy (co znosi jej „nakazowy” charakter), gdy tymczasem przykazania są nakazami par excellence - kto inny jest nadawcą (autorem, źródłem), kto inny adresatem normy.

${ }^{21}$ Por. Wj 20, 6; Pwt 5, 10. 
dwóch „duchów” pozwala panow ać nad prawe m, zamiast „być w jego niewoli”? Albo jeszcze inaczej: kto może, a kto nie może panować nad prawem (być lub nie być „w jego niewoli”) w zależności od tego, czy dajemy się prowadzić duchowi „miłości bliźniego”, czy duchowi miłości politycznej, czyli bezwarunkowej? Odpowiedzi narzucają się same: prowadzeni duchem „miłości bliźniego”, zwanym w języku Starego Testamentu duchem przymierza, a w języku nowożytnej filozofii politycznej duchem umowy społecznej, mogą wspólnie panować nad prawem, moga więc nie być w jego niewoli; prowadzeni przez ducha „miłości politycznej”, miłości władzy, miłości bezwarunkowej popadają w absolutną niewolę: nie mogą się odwołać do prawa, które z natury rzeczy ogranicza chociaż trochę nawet najbardziej despotycznego prawodawcę. Innymi słowy - relacja niezapośredniczona przez prawo wydaje człowieka na łaskę władzy. „Czy [...] przez wiarę obalamy Prawo? Żadną miarą! Tylko Prawo właściwe ustanawiamy"22. Chodzi najwyraźniej, wbrew licznym deklaracjom, nie o ,prawo miłości”, ale o ,prawo łaski”, a więc - prawo władzy.

Tę prostą prawdę powinni byli już znać słowianofile. Tym bardziej nie mogli jej nie znać na przykład rosyjscy filozofowie religijni, w tym apologeta wolności Mikołaj Bierdiajew ${ }^{23}$, a zwłaszcza nie mógł jej nie znać Aleksander Sołżenicyn, na którego biografii (podobnie jak na biografiach milionów) odcisnęła swoje niezatarte piętno polityczna miłość. Nie dokładnie taka sama, co na biografiach innych milionów, zabijanych masowo w imię miłości do Chrystusa ${ }^{24}$, ale jednak ta sama. A skoro ją zna

${ }^{22} \mathrm{Rz} \mathrm{3,} 31$.

${ }^{23}$ Por. jego ,upadek człowieka umożliwia jedynie odpowiedź w formie prawa”. M. Bierdiajew, Zarys metafizyki eschatologicznej, Kęty 2004, s. 87.

${ }^{24}$ Szacuje się, że w samych tylko „polowaniach na czarownice” zabitych zostało (po uprzednim poddaniu torturom) około 500 tysięcy osób, głównie kobiet. W wyniku kierowanej i legitymizowanej przez Kościół katolicki konkwisty zginęło (lub zmarło od chorób) w Ameryce środkowej około 20 milionów osób. To tylko najbardziej spektakularne spośród niezliczonej liczby przykładów, tym bardziej, że przykład Holocaustu odnosi się tu jedynie pośrednio (jako punkt kulminacyjny rozwoju kultury europejskiej, zakorzenionej - między innymi - w chrześcijańskim antysemityzmie). Pośrednio, ale jednak się odnosi, co przyznają nawet niektórzy katolicy: „Chrześcijański antyjudaizm stał się podstawą dla rasistowskiego, ludobójczego antysemityzmu...”. Konferencja katolików w Stanach Zjednoczonych, Nauczanie katolickie o Shoah: wprowadzając w życie „Pamiętamy” (2001). Inni z kolei zdecydowanie ten związek odrzucają: „Shoah to dzieło na wskroś nowożytnego, neopogańskiego reżymu, którego antysemityzm miał swoje źródła poza chrześcijaństwem”. Komisja do spraw Kontaktów z Judaizmem, Pamiętamy: refleksje nad Shoah (marzec 1998). 
- skoro znają ją Borys Wyszesławcew, Iwan Iljin i inni przedstawiciele rosyjskiej filozofii religijnej - to widocznie jemu i im o to chodzi: o miłość polityczną, jeśli nawet nie taką samą, to, co do istoty, tę samą miłość do Boga i do legitymizującej się z jego pomocą władzy.

Czy fascynacja siłą zainspirowała Pawła do twórczości epistolarnej? Skąpe wiadomości o życiu autora Listów nie pozwalają jednoznacznie odpowiedzieć na to pytanie, zaś interpretacja tekstu, jak by nie była uargumentowana, w ostatecznym rachunku zależy od założeń, leżących u podstaw interpretacji. Założenia te są następujące: prawo jest kulturową formą relacji między podmiotami (1); relacja między nimi może być zbudowana z panowania i posłuszeństwa, a więc być oparta na sile (na przewadze), i wtedy prawo jest formą siły, albo na umowie (na ,przymierzu”), i wtedy prawo jest formą umowy (2); „duch” (wartość podstawowa) może być albo duchem siły (ściślej - panowania i posłuszeństwa), albo duchem porozumienia (przymierza) (3); zastąpienie prawa przez „miłość”, czyli bezwarunkowe oddanie, likwiduje te resztki „zniewolenia przez prawo”, jakiemu podlega w ramach formy prawnej władza despotyczna (4), zwiększając zarazem pozaprawne zniewolenie poddanego (5); relatywizacja prawa potęguje możliwość uniknięcia „niewoli prawa”, pod warunkiem, że ujawniona zostaje immanentna dwoistość prawa jako kulturowej formy wyboru (ustanowienia) jednego z dwóch typów relacji (6); ale nawet bez spełnienia tego warunku stwarza przestrzeń dla zmiany typu relacji poprzez presję na zmianę prawnej formy tej relacji $(7)^{25}$.

Nihilizm prawny służy władzy autorytarnej, a zwłaszcza jej skrajnej formie - totalitaryzmowi. Ten zaś pożywkę ideologiczną znajdować może nie tylko w nacjonalizmie czy w ,naukowej” eschatologii. Może ją znajdować na przykład w apologii absolutnej miłości.

\section{II.}

W przeciwieństwie do Walickiego ${ }^{26}$, wspomnianego wyżej, Sławomir Mazurek w swojej interesującej książce, poświęconej „moralnej rewolu-

25 Zob. szerzej W. Paradowska, R. Paradowski, Wartości w świetle dialektycznej metafizyki wyboru, „Przegląd Religioznawczy” 2005, nr 1.

26 Ale także w przeciwieństwie np. do W. W. Sapowa, autora słowa wstępnego do wydania Etiki preobrażennogo erosa z 1994 roku i jego rozszerzonej wersji z wydania roku 2006. Kwestię, ,paradoksu prawa” pomija w swojej recenzji Etyki... N. O. Łosskij 
cji” w rosyjskiej filozofii religijnej, podejmuje, czy może raczej sygnalizuje temat ,paradoksu Prawa”. Mazurek stwierdza: „...Wyszesławcew był... filozofem religijnym, który głęboko przejął się ewangeliczną krytyką prawa i w Pawłowym «Bo gdy nie ma prawa, grzech jest w stanie śmierci» $" 27$ dostrzegł prawdę o podstawowym znaczeniu dla wszelkiej myśli moralnej, z jakichś względów od stuleci niezrozumianą i zlekceważona.

Zdaniem Wyszesławcewa punktem wyjścia wszelkiej godnej tego miana refleksji moralnej musi być stwierdzenie będące filozoficzną transpozycją słów Apostoła: zło pojawia się w świecie wraz z prawem. Należy je przy tym rozumieć jak najbardziej dosłownie - rzecz nie w tym, że wraz z prawem zyskujemy świadomość zła, które, nie zdając sobie z tego sprawy, czyniliśmy już wcześniej, ale w tym, że prawo, raz ustanowione, do czynienia zła popycha. Pojęcie prawa, którym operuje Wyszesławcew, jest przy tym bardzo szerokie - przez prawo rozumie on wszelką normę etyczna, obyczajową, religijną czy prawną w węższym znaczeniu, zwłaszcza jeśli nadano jej formę zakazu. W tym sensie złowrogim, demoralizującym prawem jest zarówno zakon Mojżesza, jak i etyka stoików, zarówno prawo rzymskie, jak i imperatyw kategoryczny Kanta ${ }^{28}$. Mazurek jednak nie dopowiada, że jedynym prawdziwym ,złem”, nie po prostu uświadamianym wraz z pojawieniem się prawa, lecz złem, do którego rzeczywiście prawo „popycha”, jest „uniwersalne” zło nieposłuszeństwa, nie zaś zabójstwo, kradzież, cudzołóstwo czy jakikolwiek inny zły czyn. Ale też - co się z tym nierozerwalnie wiąże - nie jest to „zło absolutne”, lecz to, co jest złem w kontekście etyki posłuszeństwa ${ }^{29}$.

a G. D. Gurvitch zadowala się odległą do niego aluzją (zakonniceskaja etika versus etika sublimacii). Zob. N. O. Łosskij (Recenzija na „Etiku preobrażennogo erosa”) i G. D. Gurvitch (Recenzija na „Etiku preobrażennogo erosa”), w: B. P. Wyszesławcew, Krizis industrialnoj kultuy. Izbrannyje socinenija, Moskwa 2006, s. 833 i 835.

$27 \mathrm{Rz} \mathrm{7,8.}$

28 S. Mazurek, Utopia i łaska. Idea rewolucji moralnej w rosyjskiej filozofii religijnej, Warszawa 2006, s. 175.

29 Podstawą tej ,relatywizacji” zła (ale też, odpowiednio, relatywizacji dobra) jest wyróżnienie dwóch wartości podstawowych, panowania i posłuszeństwa oraz wzajemnego uznania (równej) wolności i dwóch nie sprowadzających się do siebie nawzajem systemów etycznych: tego, w którym podstawowym złem jest nieposłuszeństwo, i tego, w którym złem jest nieuznanie przeze mnie równej mojej kompetencji etycznej innego. 
Przyjrzyjmy się więc, jak wykorzystuje Pawła i jego „,paradoks” Borys Wyszesławcew $^{30}$ w książce Etyka przekształconego Erosa, w której stawia sobie za cel zdezawuowanie i odrzucenie etyki normatywnej i zbudowanie etyki na „całkiem odmiennych podstawach”. Inspiracji do realizacji tego przedsięwzięcia szuka w chrześcijaństwie ewangelicznym, w przekształconym symbolu „Królestwa Bożego”31 , głównie jednak - w Listach świętego Pawła ${ }^{32}$. Pragnę odnotować w tym miejscu, że Wyszesławcew Pawłowi przypisuje główną zasługę przeciwstawienia prawa i łaski, chociaż w przesłaniu ewangelicznym nie dopatruje się żadnej w tym względzie odmienności, odmienności polegającej na tym, że u Pawła mamy do czynienia z odrzuceniem prawa, podczas gdy w Ewangeliach „zaledwie”

30 Borys Pietrowicz Wyszesławcew (1877-1954) był filozofem, publicystą i krytykiem literackim, z wykształcenia - prawnikiem, zresztą przez jakiś czas praktykującym jako adwokat. Lekcje filozofii pobierał u marburczyków - P. Natorpa i G. Cohena; po Nowgorodcewie przejął wykład doktryn politycznych. Do filozofii wszedł książką Etika Fichte. Osnowy prawa i nrawstwiennosti w sistiemie transcendentalnoj filosofii (1914). Mianowany profesorem na wydziale prawa został wkrótce (1922) wraz z innymi rosyjskimi intelektualistami wydalony z Rosji. Zamieszkał najpierw w Berlinie, potem w Paryżu, gdzie wraz z M. Bierdiajewem założył czasopismo „Put”, potem znowu w Niemczech, na koniec w Szwajcarii, gdzie zmarł. Główne dzieła: Etika preobrażennogo erosa. Problemy zakona i błagodati, Fiłosofskaja nisceta marksizma, Krizis industrialnoj kultury, Wiecnoje w russkoj filosofii, Serdce w christianskoj $i$ indijskoj mistike.

31 B. P. Wyszesławcew, Etika preobrażennogo Erosa, w: tegoż, Krizis industrialnoj kultury, Moskwa 2006, s. 23. Wyszesławcew nie podnosi kwestii różnic między przesłaniem Pawła a przesłaniem ewangelicznym, przeciwnie, przyjmuje ich zasadniczą tożsamość. Co zaś do symbolu „Królestwa Bożego” - jest on przekształcony w duchu gnostyckim w stosunku do jego pierwotnego znaczenia w tradycji żydowskiej.

32 Własna rosyjska tradycja pełnego rezerwy stosunku do prawa (nie mówiąc już o nihilizmie prawnym) ma swoje źródło doktrynalne w dziele Słowo o Zakonie i Błagodati metropolity Hilariona (XI w.), który budował swoją argumentację - całkowicie w duchu chrześcijaństwa pauliańskiego - na przeciwstawieniu judaizmu i chrześcijaństwa. „Hilariona w ciągu dziesięciu wieków istnienia tekstu niejednokrotnie oskarżano o antysemityzm. Pogląd metropolity można tłumaczyć na dwa sposoby: albo [...] chciał za wszelką cenę ukazać wyjątkowe właściwości wiary chrześcijańskiej, w tym przez całkowicie szczere traktowanie judaizmu jako niesamodzielnego etapu przygotowawczego; albo rzeczywiście polemizował z tradycyjnie silną żydowską wspólnotą Kijowa i z uwagi na swoje stanowisko zmuszony był zbudować agresywną i twarda prochrześcijańską apologię". L. E. Szaposznikow, A. A. Fiodorow, Istoria russkoj religioznoj fiłosofii, Moskwa 2006, s. 56. Ta próba usprawiedliwienia antysemityzmu Hilariona pomija fakt, iż jego źródła tkwią nie tyle w sytuacji społecznej Kijowa, co w świętej księdze chrześcijaństwa - Nowym Testamencie. 
$\mathrm{z}$ jego relatywizacją ${ }^{33}$. Jednak $\mathrm{z}$ uwagi na to, że interesuje mnie tu wyłącznie pogląd Wyszesławcewa na prawo, wpisany w teksty Pawła, odczytanie ewangelii przez autora Etyki... będę traktować jako drugorzędne ${ }^{34}$. Jako pierwszorzędne natomiast to, że zarówno u Pawła, jak i w ewangeliach, dopatruje się fillozof „,nowego systemu wartości”, i dopatruje się go w czymś, co się i u Pawła, i w ewangeliach (jego zdaniem również w ewangeliach) przeciwstawia Staremu Testamentowi: w opozycji prawa i łaski. Ostry i skrajny charakter tej opozycji wyrażony ma być w przytoczonych przez Pawła (odtąd przytaczać będę głównie Pawła, przytaczanego przez Wyszesławcewa) słowach: „,to, co dawne, minęło, a oto [wszystko]


czonej relacji z Bogiem. „To, co się tu przeciwstawia religii, za najwyższą wartość uznającej «Prawo», powiada Wyszesławcew, to inna i zupełnie inna wartość bezpośredniego mistycznego obcowania z Absolutem..."36. Nie chodzi o inne prawo - tę kwestię rozwinie filozof bardzo skrupulatnie $^{37}$ - chodzi o to, by nic nie zakłócało bezpośrednich stosunków człowieka z Bogiem. Ale chociaż to wszelkie zapośredniczenie jest czymś niewłaściwym $^{38}$ (zapośredniczenie przez jakikolwiek rodzaj prawa), nie

33 Polegającą na tym, że o ile w jednym miejscu mówi się o wypełnieniu prawa „co do joty” (Mt 5, 17), w innym zastępuje się je ,przykazaniem najważniejszym” (Mt 22, 37).

34 Wydobycie różnicy między przekazem ewangelicznym i przekazem Pawła nie jest bez znaczenia, jeśli z taką różnicą mamy rzeczywiście do czynienia, to znaczy z podziałem, z jednej strony, zasad na podstawowe i wtórne (a jednocześnie z podziałem na sferę transcendentną - przykazania „najważniejsze”, i immanentną - pozostałe), pozostającym na gruncie kultury, z drugiej zaś z czymś w rodzaju odrzucenia immanencji tym samym podziałem na transcendencję i immanencję, połączonym z unieważnieniem tej ostatniej; może to wyglądać na gnostyckie z ducha odrzucenie kultury, jednak tylko na pierwszy rzut oka: mimo kompleksów seksualno-cielesnych mamy u Pawła do czynienia nie tyle z odrzuceniem kultury, co z wyraźnym opowiedzeniem się po stronie kultury określonego typu - kultury dominacji i posłuszeństwa w czystej postaci.

352 Kor 5, 17 (B. P. Wyszesławcew, op. cit., s. 24).

36 Ibidem, s. 26.

37 „Zakon Moiseiew (i, w suscnosti, wsiakij zakon)...”. Ibidem, s. 28. „Było by, odnako, wes'ma nieprawilno wsiu polemiku s zakonom otnosit' tol'ko k prehodiascemu istoriceskomu jawleniju judejskoj pozitivnoj religii...”, „na samom dele antinomia beskonecno glubzhe, ibo poniatije Zakona gorazdo shire". Ibidem, s. 41.

38 Używam tu tego dość neutralnego określenia, chociaż twierdzenie, że jest czymś złym, że jest złem, w kontekście określeń, używanych przez Pawła, a za nim przez Wyszesławcewa, byłoby całkiem uzasadnione. 
pomija filozof okazji, by stwierdzić, że żydowskie prawo - przede wszystkim. A to dlatego, że się odznacza drobiazgowym $\left(\right.$ mielocnym ${ }^{39}$ ) materializmem, że ustanawia zapośredniczenie relacji z Bogiem nie na poziomie ducha, lecz na poziomie ciała ${ }^{40}$; nie tyle nawet zapośrednicza wspomnianą relację, co przegradza drogę człowieka do Boga, chociaż z drugiej strony nie jest jasne, czy całkowicie przegradza, czy tylko uniemożliwia między stronami ,intymnie serdeczny stosunek miłości, stosunek Bogosynowstwa”; więcej - nie tylko ,przegradza”, ale na miejsce „przyjaźni i synowstwa” stawia stosunek „Prawodawcy i poddanego, Władcy i niewolnika”. Prawo czyni człowieka niewolnikiem. Zatem, możemy się domyślać, to nie prawo, lecz jego odrzucenie wyzwala człowieka ze stanu poddaństwa $^{41}$. Duch Boży, albo lepiej - zwrócenie się człowieka ku niemu, czyni wolnym. „Gdzie Duch Boży, tam wolność”. Ale, zapytajmy, który „duch”? Miłości politycznej (bezwarunkowego miłowania „najwyższego”) czy miłowania bliźniego jak siebie samego? Odpowiedzi na to pytanie od Wyszesławcewa nie oczekujmy - dla chrześcijanina (filozof nieustannie deklaruje się jako chrześcijanin) istnieje tylko jeden Duch, Duch jako Jedyny. Dwa „duchy boże”, odrębne na poziomie metafizycznego doświadczenia, połączone w specyficzny sposób (na przykład taki, jak u Mateusza ${ }^{42}$, albo odwrotnie - tak, by „wzajemnemu miłowaniu” dać pierwszeństwo, zaś „,miłowaniu bezwarunkowemu”, „politycznemu”, relacji hierarchicznej - miejsce ograniczone) - to już by się nie zmieściło w żadnej ze znanych wersji chrześcijańskiego światopoglądu ${ }^{43}$.

Przy okazji wyjaśnia się, że ideału niezapośredniczenia relacji między Bogiem i człowiekiem nie należy traktować dosłownie, i to nie tylko w tym sensie, że ma być ona zbudowana z miłości i łaski (można bowiem próbować rozumieć tak zbudowaną relację jako „nie zapośredniczoną”),

39 Polskie słowo „drobiazgowy”, jakkolwiek wydaje się tłumaczeniem precyzyjnym, pozbawione jest tego ładunku oceniającego, który oddany być może np. za pomocą słowa „miałki”, a nawet „niski”.

40 „Prawo cielesnego przykazania”. Hebr 7, 16 (Wyszesławcew, op. cit., s. 25).

41 Tak by rzeczywiście było, gdyby chodziło wyraźnie o odrzucenie prawa arbitralnie ustanowionego i, co ważniejsze, zastąpienie go regułami stanowionymi inaczej.

Zob. Mt 22, 37.

43 Tym bardziej, że „miłość polityczna”, podporządkowana „miłowaniu bliźniego", nie tylko traci swój status pierwszorzędnej zasady, ale też traci swój pierwotny charakter bezwzględnego miłowania, a jej rolę przejmuje prawo, ufundowane na nowej zasadzie podstawowej. 
ale również w takim znaczeniu, które dopuszcza przynajmniej a s p e k t „cielesny” owego zapośredniczenia, aspekt kulturowy i instytucjonalny, przysługujący skądinąd tak namiętnie odrzucanemu prawu. Bo oto okazuje się, że na miejsce „obecnej Jerozolimy”, sfery poddanej prawu, nadejść ma „nowa Jerozolima”, „rozsławiony i królujący Kościół”, Wyszesławcew nazywa go „matką nas wszystkich”, sferą „nie podlegającą prawu”, „ponadprawną”, „metajurydyczną”, sferą łaski, miłości i wolności, dodając w tym kontekście słowa „trzynastego apostoła”: „Przeciw takim [cnotom] nie ma prawa!" 44 .

Paweł $^{45}$, a za nim Wyszesławcew, stoją na stanowisku przeciwstawności „ducha” i formy, w każdym razie takiej formy, jakąjest prawo. Nawiasem mówiąc, w kontekście, w którym padają powyższe słowa, o łasce akurat nie ma mowy (może dlatego, że nie jest ona cnota, a o cnoty Pawłowi tutaj chodzi), jakkolwiek do kontekstu pasuje, dzieli bowiem $\mathrm{z}$ cnotami tę domniemaną cechę bycia czymś par excellence duchowym, czymś prawem nieskażonym. Przyjmijmy, że wspomniane u Pawła (i u Wyszesławcewa) cnoty mają źródło w duchu (pamiętając o jego niezbywalnie dwoistym charakterze), ale czy to znaczy, że się bez reszty w duchu mieszcza, poza ducha nie wychodza, konieczności przyobleczenia się w formę (tu: w prawo) nie podlegają? Odwołanie się do dwoistości ducha jest tu konieczne: duch „miłowania bliźniego”, jako duch wzajemnych wymagań, przy czym wzajemnych wymagań otwarcie wyrażonych ${ }^{46}$, ma strukturę porozumienia, przymierza, strukturę umowy, a ta jest w ostatecznym rachunku źródłem ściśle rozumianego prawa ${ }^{47}$; wzajemnie stawiane warunki to nic innego, jak właśnie najogólniejsza struktura prawa. Tym samym duch i prawo (tak jak materia i forma, jak treść i forma) okazują się nierozłączne. Ale sprawy się tak mają nie tylko w przypadku ducha miłości, ale również - w przypadku ducha władzy. Ten ostatni bowiem tylko w swym kształcie ideologicznym (jako „miłość bezwarunkowa") wydaje się wolny całkowicie od pierwiastka kontraktualnego;

44 Ga 5, 23 (Wyszesławcew, op. cit., s. 28).

45 Ga 5, 22-23.

46 Duch miłości bezwarunkowej, czyli duch władzy, również jest duchem wzajemnych wymagań, i jako taki jest duchem szeroko pojętej umowy, z tym wszelako zastrzeżeniem, że strony wymagają tu od siebie nawzajem czego innego, w szczególności - strona silniejsza od słabszej wymaga posłuszeństwa, słabsza od silniejszej - „łaski”, czyli opieki.

47 Prawo szeroko rozumiane może być zarówno formą władzy, jak i przymierza (umowy). 
w swej rzeczywistości zawiera nie tylko oczekiwania - ze strony władzy - pełnego podporządkowania, ale przede wszystkim - co wydaje się na pierwszy rzut oka nieoczywiste - przyzwolenie ze strony poddanego na takie oczekiwanie. Ta skrajnie nierównoprawna umowa wydaje się w ogóle nie być umową - tak dalece fenomen władzy wydaje się samowystarczalny, tak dalece władza wydaje się niezależna od tego, nad kim jest sprawowana. Jeśli jednak uda nam się za fenomenem panowania dostrzec r e 1 a c j ę władzy, wówczas dostrzeżemy wzajemną zależność, właściwą wszelkiej relacji, oraz element wzajemnych wymagań, w sposób konieczny wymuszający formę. Tą formą jest właśnie prawo - reguły utrwalające relację, skądinąd wywodzące się z ducha. Duch jest „boży”, prawo jest ludzkie - uważa Wyszesławcew ${ }^{48}$. Pogląd Pawła i Wyszesławcewa, pogląd, by tak rzec, skrajnie religijny, polega na twierdzeniu, że duch może wprawdzie przybrać formę, ale jej przybierać nie musi, i w tym sensie flat ubi vult. Zarazem trudno tu cokolwiek przesądzić ostatecznie - obaj autorzy zdają się raczej skłaniać do przekonania o rozdzielności tego co boskie, boskich wartości, i tego co ludzkie - w tym wypadku prawa. Ta rozdzielność akcentowana jest szczególnie dobitnie w stwierdzeniu, że „prawo nigdy nie zawiera w sobie bezpośrednio [podkr. Wyszesławcewa] boskich wartości”49, między nimi a prawem jest bowiem „grzeszna” natura ludzka. Bóg, duch, boskie wartości z jednej strony, reguły ludzkie (prawo) z drugiej. Ludzkie, bo ostateczny kształt nadaje im „ludzki pośrednik”, na przykład Mojżesz. Jednocześnie użycie słów „boskie wartości”, albo prościej - ,,wartości”, zamiast (albo jako synonimów) Boga i ducha, przenosi zagadnienie na płaszczyznę filozoficzną: jaki jest związek (włączając w to ewentualny brak związku) między wartościami, tak czy inaczej transcendentnymi, a prawem pozytywnym. Na razie pozostajemy na etapie konstatacji dość banalnej: w ludzkim, pozytywnym, prawie jest coś „nie-boskiego” (musi ono bowiem „być przystosowane do ducha narodu”), ale zarazem coś „,boskiego” - ,jeśli w prawie jest element boskości, to dodatkowo jest

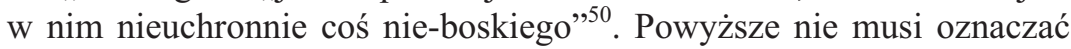
(chociaż wiemy, że u Pawła oznacza), że prawo jest złem i źródłem zła, a tylko, że nie jest doskonałe, ale też, że może się do doskonałości przybliżać, jeśli pośrednik-prawodawca orientuje się na „wartości”. To stawia sprawę na ostrzu noża: zastąpić prawo bezwarunkową miłością do Boga

\footnotetext{
48 Zob. Wyszesławcew, op. cit., s. 29.

49 Ibidem, s. 31.

50 Ibidem, s. 30.
} 
(a zapewne również do wywodzącej się od niego władzy), czy skoncentrować się na doskonaleniu prawa. Paweł wybiera, jak wiadomo, opcję pierwszą. Opcja druga wymaga rozstrzygnięcia, czy na pewno duch jest jeden, nawet jeśli to rozstrzygnięcie nie zostaje ujawnione. Doskonalenie prawa, w zależności od tego, czy duch jest jeden, czy duchy są dwa ${ }^{51}$, będzie się oczywiście dokonywać ze względu na wyższą zasadę. W jednym wypadku będzie to efektywność w sprawowaniu władzy, w drugim - wzajemnie równe traktowanie ${ }^{52}$.

Zaznaczę na marginesie, że w relacji ducha i formy mamy do czynienia - wbrew religijnemu stanowisku - z czymś w rodzaju przyrodniczej konieczności (konieczności przyoblekania się ducha w formę, ale też konieczności zakorzenienia formy w duchu); i tak jest w istocie, chociaż nie do końca: element wolności, który się wkrada w uznaną wyżej konieczność, jest nierozerwalnie związany z dwoistością ducha - z tym, że duch może być albo duchem władzy, albo duchem miłości, i z koniecznością (znowu koniecznością) wyboru ducha. Stanowisko religijne (nie tylko skrajnie religijne) polega na utożsamieniu (jak u Pawła) lub przynajmniej na niedostatecznym rozróżnieniu (jak u Mateusza ${ }^{53}$ ) obu tych duchów, i tym samym na ukryciu podstawowej prawdy metafizycznej - konieczności i wolności wyboru (takiego czy innego) ducha ${ }^{54}$.

51 Duch siły i duch umowy, „duch” autorytaryzmu i ,duch” demokracji.

52 Mogłoby się wydawać, że Paweł akurat do czegoś takiego nawołuje (zob. Ga 5, 13-14), gdyby nie fundamentalna dla niego negacja prawa (które mogłoby tego rodzaju postawy utrwalać i promować), gdyby nie zacieranie różnicy między wzajemnym miłowaniem i ,wzajemnym służeniem” a miłowaniem i oddaniem bezwarunkowym, a zwłaszcza, gdyby nie absolutyzacja i sakralizacja władzy.

53 „Drugie, podobne temu”.

54 A praktycznie rzecz biorąc - konieczności i wolności wyboru odpowiedniej subordynacji duchów: podporządkowania ducha miłowania bliźniego jak siebie samego duchowi panowania i posłuszeństwa (duchowi „miłości” bezwarunkowej), albo odwrotnie - podporządkowania ducha hierarchii i posłuszeństwa duchowi równych wzajemnych wymagań i porozumienia.

Nie bez znaczenia jest tu również różnica w religijnym i niereligijnym rozumieniu transcendencji. W religijnym (ściślej - chrześcijańskim, chociaż nie tylko) jej rozumieniu mamy do czynienia z całkowitą separacją transcendencji i immanencji, zaś próby przedarcia się od drugiej do pierwszej nie przynoszą oczywistych rezultatów (potwierdza to nie tylko psychologia, ale i teologia). W rozumieniu nie religijnym (zwłaszcza w ramach dialektycznej metafizyki wyboru) transcendencję wyodrębnia z bytu to, że wybór metafizyczny wartości podstawowej (posłuszeństwa versus wzajemnego uznania równych kompetencji) jest w os ta tec zny m rachunku wolny od kulturowej i przyrodniczej determinacji, zaś łączy podstawowa relacja, 
Wyszesławcew silnie akcentuje konieczność naruszenia prawa (,,jeśli konkretna miłosna twórczość rozrywa formalne ramy normy"), prawa, które nie jest w stanie „przewidzieć całego bogactwa życiowych sytuacji”. Przyznaje więc, że miłość bliźniego może wejść w konflikt z wolą władzy (która, jak wiemy od Pawła, w całości pochodzi od Boga), z jej wolą prawnie wyrażoną, nie wyobraża sobie jednak prawa, które mogło by być uzgodnioną formą woli ,wzajemnie się miłujących”, wzajemnie uznających swą równą prawodawczą kompetencję podmiotów. Wzywając, za Pawłem, do odrzucenia woli Boga, wyrażonej w prawie, bluźni przeciw jego władzy. Może więc i Paweł przeciw tej władzy bluźni? I czy to jeszcze dialektyka ${ }^{55}$, czy już schizofrenia? Albo fundowanie zupełnie nowej religii, bez „Boga”, a nawet bez jego „Syna”, a tylko z przymusem wiary w jego zmartwychwstanie, religii miłości czyli władzy? Ale wróćmy do Wyszesławcewa.

Zarzut odgradzania człowieka od Boga, stawiany Prawu, jest bodaj najważniejszy, ale nie jedyny. Prawo mianowicie, chociaż stara się walczyć ze złem i „zabraniać przestępstwa”, ponosi klęskę, bo na zło odpowiada złem („obratnym złom”), gdy tymczasem należy „pozytywnie czynić dobro", co jest w stanie czynić, zdaniem Wyszesławcewa, tylko miłość. Chociaż przykłady, na jakie się powołuje, mogą co najwyżej potwierdzić tezę, że prawo nie może objąć wszystkich przypadków, i dlatego potrzebuje dodatkowej instancji (czy będzie to tak czy inaczej rozumiana „miłość”, czy „sumienie”, czy doświadczenie życiowe sędziego, czy utrwalone na piśmie zasady konstytucyjne itp., itd.); nie mogą natomiast uzasadniać zastąpienia prawa przez miłość czy wiarę jako „antycypację (predvoskhiscenije) ideałów Królestwa Bożego" ${ }^{\text {"56 }}$. Wyszesławcew ma tu na myśli zapewne ideały Kościoła chrześcijańskiego, wcześniej bowiem z nim właśnie utożsamia ,nową Jerozolimę” i augustiańskie Państwo

w obrębie której dokonywane są zarówno metafizyczne wybory, jak i kulturowe decyzje, którą jest relacja między jednostkami jako podmiotami. Szczegółowo zob. np. W. Paradowska, R. Paradowski, Wartości w świetle dialektycznej metafizyki wyboru, „Przegląd Religioznawczy” 2005, nr 1; tychże Podmiotowość jako transcendecja. Przyczynek do definicji podmiotowości politycznej, ,Środkowoeuropejskie Studia Polityczne" 2005, nr 1 oraz Kantowskie antynomie czystego rozumu i ontyczny status Boga, „Przegląd Religioznawczy” 2006, nr 4.

55 „Filozofia apostoła Pawła z jej dialektycznym przeciwstawieniem prawa i łaski...”. B. P. Wyszesławcew, Wiecnoje w russkoj filosofii, w: B. P. Wyszesłąwcew, Krizis industrailnoj kultury. Izbrannyje socinenija, Moskwa 2006, s. 659.

${ }^{56}$ Wyszesławcew, Etika..., op. cit., s. 30. 
Boże („to civitas Dei, to Królestwo Boże, to Nowa Jerozolima [...], to carstvujuscaja Cerkov”, ${ }^{, 5}$ ). Czy o to chodziło Pawłowi? „Formalnie” za budowniczego kościoła uważany jest Piotr, ale to intensywna agitacja Pawła na obszarze całej niemal ekumeny spowodowała, że było kogo organizować w tak zwany później „kościół powszechny”. Zatem to kościół, zamiast prawa, ma być drogą człowieka do Boga. Trudno jednoznacznie stwierdzić, czy tak się na to zapatrywał Paweł (tym bardziej, że za jego czasów ta „wspólnota wiary” jeszcze się nie zinstytucjonalizowała), za to najwyraźniej taki właśnie jest w tej sprawie pogląd Wyszesławcewa. Jest to jednak pogląd, zbudowany z pawłowego materiału - to właśnie kościół stał się, zwłaszcza od czasu połączenia z cesarstwem, beneficjentem tego, co miało się rzekomo należeć tylko Bogu - bezwarunkowej miłości, czyli posłuszeństwa. A wraz z kościołem beneficjentem stało się cesarstwo, władza bowiem ,pochodzi od Boga"58. Relatywizm prawny musiał (u Pawła, ale także, przynajmniej na razie, u Wyszesławcewa) ustapić prawnemu nihilizmowi. Z całkowicie realistycznej i umiarkowanej przesłanki o ludzkim i ,niedoskonałym” charakterze prawa wyciągnięty został radykalny wniosek o konieczności wyeliminowania prawa i zastapienia go czymś zasadniczo od niego różnym - łaską i cnotami, w tym - bezwarunkową miłością do tego, kto nad nami ${ }^{59}$.

Wśród powołanych przeciwko prawu kategorii na jedno z pierwszych miejsc wysunięta została przez Pawła i jego zwolenników, w tym przez Wyszesławcewa, kategoria wiary. Ideologiczny status pojęcia wiary ujawnia mimo woli Wyszesławcew pisząc, że ,przez wiarę zbudował Noe arkę ratunkową, przez wiarę Abraham podporządkował się nakazowi pójścia do ziemi obiecanej..." ${ }^{60}$ itd. Jeśli jednak (całkowicie w zgodzie z duchem i literą Starego Testamentu) stwierdzimy, że u podstaw tego wszystkiego leżało p r z y m i e r z e z Bogiem (nie tyle wiara weń, ani nawet Pawłowa „obietnica”, co przymierze z Nim), może się okazać, że przeciwstawiać należy nie tyle wiarę (miłość itd.) i prawo, co wiarę i przymierze oraz pra-

57 Ibidem, s. 28.

58 Nawet świadomość wyłącznie kulturowego statusu Boga (jego statusu jako symbolu) nie czyni z tej tezy formuły uniwersalnej, o ile bowiem w jednym przypadku władza rzeczywiście ,pochodzi od Boga”, o tyle w drugim pochodzi od Boga i od człowieka jednocześnie, czyli „od przymierza”.

59 Na tym zapewne polega ,rewolucja moralna”, wydobyta w podtytule jednej z książek Sławomira Mazurka.

60 Wyszesławcew, op. cit., s. 32. 
wo wiary i prawo przymierza. W ogóle zaciekłość w zwalczaniu prawa wydaje się pozornie przeciwko prawu skierowaną, a faktycznie - przeciwko przymierzu jako jego podstawie i istocie. Albo inaczej (i bardziej w zgodzie z potoczną intuicją): pojęcie wiary zaciera różnicę między władzą i umową, między posłuszeństwem i przymierzem. Można też powiedzieć, że jest wiara posłuszeństwa i wiara przymierza (wiara w posłuszeństwo $\mathrm{i}$ wiara $\mathrm{w}$ przymierze), $\mathrm{i}$ to jest w sposób oczywisty nie ta sama wiara ${ }^{61}$.

Byłoby niesprawiedliwością wobec Wyszesławcewa przypisywanie mu jakiegoś prymitywnego aksjologicznego monizmu. Na stronie 34 cytowanego przeze mnie wydania wyraźnie (podnosząc to nawet do rangi tytułu jednego z podrozdziałów) autor przeciwstawia sobie dwa systemy wartości. Zdawać by się mogło, że jest to dobry punkt wyjścia do wydobycia się z ideologicznej pułapki, jaką zastawia monizm na swoich wyznawców, zacierając różnicę między „duchami” (albo, inaczej, z góry ustanawiając „jedynie właściwą" ich subordynację). Dualizm Wyszesławcewa okazuje się jednak pozorny - okazuje się bowiem, że jeden system wartości związany jest u niego z ,duchem”, drugi zaś - z jego formą, nie zaś z innym „duchem”. Wyszesławcew przeciwstawia sobie „Królestwo Boże” i prawo, łaskę i prawo, Ducha i prawo, miłość i prawo, a także prawo i „swobodną twórczość”. W każdym przypadku przeciwstawia sobie ducha i formę ducha - wartość i jej postać kulturową. Relacja „ducha” i jego kulturowej formy jest oczywiście antynomiczna, ale to nie wszystko. U Wyszesławcewa systemowi wartości nie zostaje przeciwstawiony inny system wartości, lecz jedynie jakaś forma kulturowa, może zresztą nawet odpowiadająca innemu systemowi wartości. To zresztą (to, że jest to forma innego „ducha”) nie jest jednak u Wyszesławcewa (podobnie zreszta jak u Pawła) wyraźnie powiedziane. Jest to raczej dosyć świadomie ukryte.

Prawo nie wyczerpuje form, w jakich „duch”, boże królestwo itd. itp. występować mogą, nie ulega jednak wątpliwości, że jest jedną z najważniejszych form kulturowo zobiektywizowanych wartości. Istnieją dwie drogi, powiada swoim nienazbyt filozoficznym językiem filozof Wy-

61 Chrześcijańskiemu (i ogólnie - religijnemu, może z wyjątkiem buddyzmu) wyznaniu wiary w Boga jako sprawcę wszystkiego co dobre można i należy przeciwstawiać wyznanie wiary w siebie i innego; będzie to inna wiara również w tym znaczeniu, że o ile wiara w dobro bytu nadrzędnego ma charakter irracjonalny, może nas bowiem z jego strony spotkać co najwyżej łaska, o tyle racjonalność tej drugiej wiary zależy od wzajemnych wymagań, jakie sobie stawiamy. 
szesławcew, droga prawa i droga wiary w Chrystusa. W kontekście „dwóch systemów wartości” powraca filozof do kwestii zasadniczej niezgodności prawa i łaski: ,prawo i łaska Chrystusowa są nie do pogodzenia (niesowmiestimy), jak nie do pogodzenia są przekleństwo i zbawienie, niewola $\mathrm{i}$ wolność..., «zasłona na serce» $\mathrm{i}$ «serce otwarte na Boga»"62. W jakim wszelako sensie są one nie do pogodzenia? Pomińmy tu liczne cytaty z Pawła, one tylko dodatkowo ilustrują generalną tezę o zasadniczej przeciwstawności prawa i łaski. Wyżej stwierdziłem, że chociaż określona sprzeczność istnieje (i to naturalne) między duchem i formą, a więc duchem i prawem, to prawdziwa sprzeczność istnieje między różnymi duchami - duchem miłości bezwarunkowej i duchem miłowania bliźniego jak siebie samego. Nawet sprzeczność między formami tych duchów nie musi być w każdym przypadku tak głęboko sprzeczna, jak sprzeczność między duchami - formy są stopniowalne (prawo może być mniej lub bardziej autorytarne, mniej lub bardziej demokratyczne), to podstawowe zasady naprawdę się wzajemnie wykluczają. Sprzeczność między prawem i łaską istnieje rzeczywiście, ale jako sprzeczność między formami, a nie jako sprzeczność między formą i duchem. Przy czym można mówić o dwóch różnych sytuacjach, w których ta sprzeczność może mieć różne natężenie.

Przypomnijmy: jest prawo siły i prawo przymierza. „Łaska” wyraża sytuację, w której władza wyraża swą wolę w sposób jak najmniej uzależniony od woli poddanego. Prawo, nawet prawo władzy absolutnej (o żadnym innym w tym kontekście nie może być mowy), ogranicza tę władzę, stwarza po jej stronie jakieś zobowiązanie, stwarza tej władzy ramę prawną, a więc czyni ją mniej absolutną - zapośredniczona przez prawo relacja władzy zawiera przynajmniej śladowe ilości kontraktualizmu. W tym sensie oparcie relacji władzy z poddanym na łasce jest dla niej korzystniejsze, niż oparcie jej na prawie, o ile władza nastawiona jest na samopotęgowanie, na bycie władzą absolutną. Oparcie władzy na prawie jest zawsze w mniejszym czy większym stopniu dzieleniem się władzą. Władza absolutna (władza absolutu) ma być z definicji władzą niepodzielną. Prawo jest więc rzeczywiście nie do pogodzenia $\mathrm{z}$ łaską, bo jest nie do pogodzenia z dosłownie pojętą władzą absolutną, a więc - z władzą totalną.

62 Wyszesławcew, op. cit., s. 35. Wyszesławcew odwołuje się tu nawet do terminologii heglowskiej, nazywając „prawo” tezą, „łaskę” zaś antytezą, samą zaś relację prawa i łaski antynomią; przestrzega jednak przed syntezą: „,wsiakoje smieshenije i sowmiescenije etih sistem dolzhno byt' otwiergnuto". Ibidem, s. 36. 
Jeszcze bardziej nie do pogodzenia z łaskąjest prawo jako forma przymierza, jako forma umowy. Przymierze łączy się z wzajemnymi wymaganiami, wzajemnymi zobowiązaniami, nie może więc być mowy o tym, by łaska (a więc dowolność w wypełnieniu zobowiązania) mogła zastąpić zobowiązanie, którego wypełnienia można wymagać. Tu dopiero prawo jest całkowicie, jest absolutnie nie do pogodzenia z łaską. O ile w systemie władzy absolutnej (przy czym w rzeczywistym, a nie wyidealizowanym systemie „bezwarunkowego miłowania”) łaska i prawo z trudem się uzupełniają, ale jednak uzupełniają, o tyle w systemie prawa opartego na przymierzu, na porozumieniu, na umowie nie ma w ogóle miejsca dla łaski. Łaska, czego nie mówi już ani Paweł, ani Wyszesławcew, jest w pełni ,antytezą" jedynie prawa pochodzącego z umowy ${ }^{63}$.

I dlatego Wyszesławcew opowiada się przeciwko umowie.

Stwierdziłem wyżej, że Wyszesławcew, podobnie jak Paweł, odrzucając pochodzące od Boga prawo „bluźni” przeciwko niemu, bluźni przeciwko jego władzy. Była to zresztą raczej sugestia niż przypuszczenie, tym bardziej, że wyrażona w sposób niezbyt zdecydowany, dopuszczająca taką mianowicie wątpliwość, że nie zapośredniczony przez prawo stosunek między władzą i poddanym, a więc odrzucenie prawa, niekoniecznie musi osłabiać autorytet władzy, przeciwnie, może prowadzić do jej umocnienia, pod warunkiem wszelako, że się władza w swoich stosunkach z poddanym może obejść bez prawa, a to daleko nie każda władza potrafi. Ale zapewne zarówno Paweł, jak i Wyszesławcew mieli na myśli taką władzę, która potrafi ${ }^{64}$.

Wyszesławcew nie mówi tego wprost, wydaje się jednak, że zrozumiał, co w Starym Testamencie przeciwstawia się koncepcji władzy, która potrafi rządzić bez pośrednictwa prawa. Tym czymś jest pojęcie przymierza, jest samo przymierze jako fundament prawa. „Centralnym pojęciem starotestamentowej etyki i religii, pisze Wyszesławcew, jest samo pojęcie «Przymierza» («Zawieta») [...], czyli pojęcie «związku» i «umowy». U jego podstaw leży związek, wierność związkowi i umowie, uzasadniającej

63 Prawo oparte na sile ma strukturę posłuszeństwa i łaski, prawo oparte na przymierzu ma strukturę wzajemnego uznania równych statusów stron. Archetypem pierwszego z nich jest arbitralny zakaz spożywania owoców z drzewa wiadomości dobra i zła, drugiego - epokowa konstatacja starotestamentowego Boga: „,teraz człowiek stał się taki jak My, zna dobro i zło”, połączona ze złożoną człowiekowi ofertą przymierza.

64 Por. S. Żiżek, Kukła i karzet, op. cit., s. 143. 
związek - między Bogiem i narodem, między jednostkami składającymi się na naród"65. Mamy tu do czynienia z prawdziwą „umową społeczną”, stwierdza nad wyraz trafnie filozof. Jednak stwierdzenie tego nie oznacza oczywiście akceptacji. Takie „uwikłanie” Boga w umowę ${ }^{66}$, czynienie go zobowiązanym, obniżenie jego statusu do roli strony nie wydaje się chrześcijaninowi Wyszesławcowi właściwe. Świadczy o tym chociażby jego analiza nowotestamentowego zakazu przysięgi jako odrzucenia umowy, przysięgą pieczętowanej.

Królestwo Boże nie może się opierać na umowie, stwierdza Wyszesławcew, chociaż to sam Bóg, zgodnie ze starotesamentowym przekazem, ustanowił przymierze. Można by więc na tej podstawie domniemywać, że na nim, jak najbardziej, może być ufundowane „królestwo boże”. Tymczasem - „nie wolno się umawiać w sprawie wartości absolutnych"67. A jeśli - znowu zgodnie $\mathrm{z}$,wolą Boga" wyrażoną w Starym Testamencie - samo przymierze jest wartością absolutną (tu: przymierze między Bogiem i człowiekiem), podobnie jak na etapie „drzewa wiadomości złego i dobrego", ale i później, aż po dzień dzisiejszy, taką absolutną wartością jest bezwzględne posłuszeństwo, albo, inaczej mówiąc, jeśli immanentny światu wartości jest ich dualizm? „Miłość do Boga jako Ojca, powiada Wyszesławcew, nie jest umową", ale czy nie jest to stwierdzenie arbitralne, związane skądinąd z określonym typem kultury (,,ja tebia porodił, ja tebia i ubiju"68) i wcale nie tak oczywiste, jak może się na pierwszy rzut oka wydawać? „Także miłość do braci nie jest umową” (siostry Wyszesławcew pomija, potwierdzając tym mimo woli podejrzenie o kulturo-

65 Wyszesławcew, op. cit., s. 43-44.

66 Zob. R. Paradowski, ,, Stworzenie człowieka” i wzory wartości. Biblia jako księga kultury, „Przegląd Religioznawczy” 2005, nr 2.

67 Ibidem, s. 44. I tak jest w istocie - wartości podstawowe jako ,absolutne” są przedmiotem koniecznego wyboru, nie zaś umowy. Inna rzecz, że w ramach przymierza jako wartości podstawowej wszelkie inne wartości są umowne, o czym właśnie wartość podstawowa decyduje - żadna opinia co do wartości nie może być jednostronnie narzucona. Co innego w ramach wyboru panowania i posłuszeństwa jako wartości podstawowej: wszystkie wartości pochodne, jako w niej zakorzenione, leżą w kompetencji decyzyjnej strony silniejszej, i dlatego nie podlegają dyskusji.

68 „Ustanowionym” (jako typ kultury właśnie) już w Księdze Rodzaju, poprzez boskie klątwy, spośród których wyróżniają się dwie - odmówienie kobiecie zdolności myślenia (wbrew oczywistości, bo pierwsza „odnotowana” w Biblii praca myślowa to praca myślowa kobiety), potępienie „słuchania żony”, a nade wszystko zapowiedź, że „ku twemu mężowi będziesz kierowała swe pragnienia, on zaś bę dzi e pa nował nad tobą". Rdz 3, 15, 17, 16. 
we uwikłanie swojego rozumienia absolutu - R.P.). Tu już musimy pójść dalej i stwierdzić, że chociaż miłość do wszelkiej władzy (w tym do Boga) może być rozumiana jako bezwarunkowa - w każdym razie taki rodzaj relacji jest tu postulowany (jakkolwiek metafora (,,jak Ojca”) sugeruje tylko typ, patriarchalny typ, relacji, a nie relację jako taka), to już ,miłowanie bliźniego j a k s i e b i e s a m e g o" nie może być w tym samym znaczeniu postulowane jako absolutne, lecz właśnie jako warunkowe, a więc jako par excellence umowne. Nie w tym znaczeniu, że będę cię miłować, o ile ty mnie będziesz miłować, ale w tym, że sam miłuję, bo chcę być miłowany, a więc wzajemnie od siebie wymagamy równego traktowania (jednakowego „miłowania”).

Tego rodzaju interpretacja miłowania bliźniego jak siebie samego jako umowy, gwarantowanej przez równe sobie strony, nie zaś przez wyższą władzę (choćby i „,boską”), ze względu na którą ,,przykazanie” jest przestrzegane, ale także interpretacja ,miłowania Boga” jako umowy, choćby i nierównoprawnej ${ }^{69}$, nie wydałaby się Wyszesławcewowi możliwa do zaakceptowania z uwagi na jego chrześcijańską autoidentyfikację. Prawnik Wyszesławcew dostrzega konstytutywną rolę umowy w powstaniu narodu (a także, najwyraźniej, rolę umowy w kształtowaniu wszelkiego prawa), przypomina grecki i rzymski kult prawa, jednak jego monizm aksjologiczny nie pozwala mu na jej rozciagnięcie na sferę wartości podstawowych: uważa, że „to, co wyższe”, musi być ponad umową i ponad prawem. Chrześcijanin Wyszesławcew stwierdza zarazem (za Pawłem), że „,narody” niczego takiego nie mają: ,cały świat «narodów» żyje w prawie i nie zna i nie widzi niczego wyższego" [podkr. R.P.] ${ }^{70}$. To, co wyższe nie jest właściwe ludziom jako takim, lecz tylko niektórym $\mathrm{z}$ nich, mianowicie chrześcijanom.

Prawo nie wyczerpuje się w prawnoorganizacyjnym porządku narodu, prawo to również ,prawo natury”, ,zapisane w sercach”. Mogłoby się wydawać, że to ono powinno w roli pośrednika zastąpić prawo pozytywne. Rzecz w tym jednak, że również „prawo natury” może wiązać strony relacji. Odwołanie się Wyszesławcewa do prawa „w szerokim rozumieniu”, a więc nie tylko do prawa żydowskiego, ale i do „prawa natury”, a także do „prawa moralnego" ${ }^{, 71}$ ma służyć usunięciu jakichkolwiek wątpliwości

69 Relacja panowania i posłuszeństwa zależy również od strony słabszej, której uznanie silniejszego jako panującego jest warunkiem sine qua non samej relacji.

70 Wyszesławcew, op. cit., s. 42.

71 Zob. ibidem, s. 49. Utożsamiając prawo z wszelką,,imperatywną normą” Wyszesławcew nie zauważa, że pierwsze przykazanie w wersji starotestamentowej, ale także 
co do tego, czy zasada kontraktualna powinna być całkowicie przezwyciężona. Pozwala to jeszcze raz wyrazić przypuszczenie, że Wyszesławcew, uczeń Nowgorodcewa ${ }^{72}$, wszelkie prawo wiąże z zasadą kontraktualną, chociaż w ostatecznym rachunku czyni to tylko po to, by wszelkie prawo ostatecznie zdezawuować i odrzucić i tym samym jednoznacznie i zdecydowanie opowiedzieć się, za Pawłem, po jednej stronie a k s j o lo g i c z n e g o sporu. Oczywiście ani w wersji Pawła, ani w wersji Wyszesławcewa, nie jest to s p ó $\mathrm{r}$ aksjologiczny w sensie ścisłym (między podstawowymi wartościami), lecz spór między wartością „wyższą” i wartościami „państwa ziemskiego", a w istocie - zważywszy Pawła, ale także Wyszesławcewa, epitety pod adresem prawa - spór między Wartością i Antywartością. Wybór wartości przybiera (zarówno u Pawła, jak i u Wyszesławcewa) ideologiczną postać absolutnego oddania umiłowanej władzy. Mając do wyboru porządek, oparty na wzajemnych wymaganiach i ich otwartej artykulacji oraz porządek, oparty na wymaganiu jednostronnym, połączonym z dobrowolną rezygnacją z jakichkolwiek wymagań (po drugiej stronie relacji), zarówno Paweł, jak i Wyszesławcew, wybierają ten ostatni.

Warto zauważyć, że Wyszesławcew nie do końca wytrzymuje napięcie, związane z pawłowym radykalizmem, wymagającym odrzucenia nie tylko prawa pozytywnego i prawa natury, ale także moralności. „Można jeszcze wytrzymać, kiedy dezawuuje się zewnętrzne rytualne prawo, kiedy odmawia się wartości prawu pozytywnemu albo pozytywnemu etosowi i życiu w jego historycznej względności, ale kiedy zabiera się nam prawo natury, prawo zapisane w sercach, to co najlepsze i najwyższe, co jest w prawie, wówczas zdać się może, że wszelki grunt moralny usuwa się spod nóg i wszelka etyka znika”. Wyszesławcew kończy wywód akademicką z ducha deklaracją wątpliwości: „Aporia wymaga dalszych badań". Filozof nie jest gotów zaakceptować do końca totalitarnego przesłania. Zarazem jednak z konstruowania nienormatywnej etyki nie rezygnuje $^{73}$.

„najważniejsze przykazanie” w wersji nowotestamentowej, nie mówiąc o „miłości” w rozumieniu pawłowym jest właśnie taką ,imperatywną normą". Za kryterium wyróżnienia imperatywnej normy można uznać sytuację rozłączności nadawcy i adresata normy; jedyną ,nieimperatywną normą” byłoby w tym kontekście „przykazanie miłowania bliźniego".

${ }^{72}$ Na temat filozofii prawa Pawła Nowgorodcewa zob. zwłaszcza A. Walicki, Filozofia prawa rosyjskiego liberalizmu, Warszawa 1995.

${ }_{73}$ Zdanie powyższe mogłoby być odebrane jako ukryty zarzut, gdy tymczasem sam zamiar skonstruowania etyki nienormatywnej jest jak najbardziej chwalebny, 
Ale może niepotrzebnie wystraszył się totalitarnych konsekwencji pawłowej - i w efekcie również swojej - deprecjacji prawa? Może Paweł w ogóle nie jest „ojcem-założycielem” totalitaryzmu, tym bardziej, że niezbędny warunek jego realizacji spełniony został dopiero później, kiedy połączony z „władzą świecką” kościół chrześcijański przyswoił sobie boską kompetencję wymuszania bezwzględnego posłuszeństwa?

Nie da się zaprzeczyć, z jednej strony, że stawiając na ostrzu noża kwestię tego, w jakim „nakazie” wyczerpuje się („wypełnia się”) całe Prawo, wymienia Paweł jedynie „miłowanie bliźniego swego jak siebie samego”, całkowicie pomijając w tym kontekście najważniejszą - według Mateusza - miłość do Boga, skądinąd, jak wiemy, nieobwarowaną żadnymi warunkami, w tym, zwłaszcza, warunkiem wzajemności. Nie da się też zaprzeczyć, że brawurowy w swym wyrazie artystycznym Hymn o miłości mógłby sam w sobie „usprawiedliwić” Pawła ${ }^{74}$, gdyby nie - a to już z drugiej strony - reinterpretacja przymierza w duchu całkowitego oddania (obietnicy i oddania), a także co najmniej równa apologii miłości apologia władzy $^{75}$. Wspomniane wyżej wątpliwości Wyszesławcewa mogłyby go „usprawiedliwić” jeszcze bardziej, niż dana wyżej okrojona interpretacja

i byłby chwalebny (a w każdym razie skuteczny) w wypadku Wyszesławcewa, gdyby autor ten zrezygnował z monizmu oraz, co się z nim wiąże, z prymatu prawdy nad wolnością.

74 Jednak tylko artystycznie, ale już nie filozoficznie; po tym, jak z wielką mocą podkreślone zostało znaczenie miłości („Gdybym mówił językami ludzi i aniołów, a miłości bym nie miał..." itd.) i poeta przechodzi do ukazania jej esencji, mowa jest tylko o tym, co w miłości pasywne (,miłość nie zazdrości, nie szuka poklasku...” itd.). Brak ujęcia aktywnego aspektu miłości może dziwić tym bardziej, że w dalszej części Hутпи zapowiedziano przyjście tego, „,o jest doskonałe” i zniknięcie tego, „,o jest tylko częściowe" (por. 1 Kor 13,$1 ; 4-8 ; 10$ ); można to zrozumieć tylko wtedy, gdy przyjmiemy, że nie miłość jest tu całością, zaś to, co występuje tu pod nazwą miłości jest jednostronnym i bezwarunkowym oddaniem ,temu co wyższe”. Chyba, że między wersem 9 i 10 brakuje kilku wersów, które do aktywnego aspektu miłości mogły się odnosić, zapewniając jej obrazowi całościowy charakter.

${ }^{75}$ Być może jest to wynik pracy wielu autorów, których zbiorczym pseudonimem jest imię Pawła (nie wykluczone, że rzeczywistego autora jakiejś, niemożliwej dziś do ustalenia, części przypisanych mu tekstów). Oznacza to jednak tylko tyle, że rozstrzyga interpretacja, zarówno instytucjonalna, a więc kościelna, jak i logiczna; ta ostatnia jednak nie jest upoważniona do dowolnego dzielenia tekstu. W sprawie wątpliwości co do autorstwa zob. A. Badiou, Święty Pawet. Ustanowienie uniwersalizmu, op. cit., s. 41 n. Por. też A. Schweitzer, The Misticism of Paul the Apostle, ET., New York-London 1931. Cyt. za A. Szweicer, Mistika apostoła Pawła, w: Christos ili zakon? Apostol Pawet głazami nowozawietnoj nauki, Moskwa 2006, s. 61-62. 
Pawła może usprawiedliwić samego Pawła, gdyby nie to, że „to, co boskie" (przy czym raczej z Mateusza, niż z okrojonej interpretacji Pawła, a więc raczej miłość bezwzględną do Boga, niż „miłowanie bliźniego jak siebie samego") filozof skłonny jest bez wahania oddać kościołowi, jemu deklarując bezwzględne posłuszeństwo.

Wybór Wyszesławcewa jest więc w pierwszym rzędzie wyborem politycznym, stąd odwołanie się do autorytetu ,apostoła” odgrywa już tylko rolę wspomagającą i legitymizującą. Warto jednocześnie zdawać sobie sprawę z tego, że to, co tak autorytatywnie stwierdza Paweł - że prawo jest źródłem zła - zawisło od zatarcia różnicy między tym, co metafizyczne, a więc absolutne, i prawdą empirycznego uogólnienia. Prawo rzeczywiście - zwłaszcza u osób niedojrzałych lub u osób z problemami psychicznymi - często wywołuje odruch odrzucenia. Dotyczy to w tej samej mierze prawa-rozkazu, co prawa-porozumienia. Nie tylko bowiem za prawem pierwszego rodzaju stoi siła, w tym wypadku - siła władzy, ale i za tym drugim kryje się siła porozumienia i siła wzajemnego zobowiązania, której jednostka nierzadko nie może psychicznie sprostać, zwłaszcza gdy czuje się jakoś wykluczona z grona umawiających się stron. Pragnienie miłości i łaski wygląda więc na psychologiczną reakcję na wykluczenie, może być zatem uznane za ukryta, psychologiczną i jednocześnie ideologicznie przekształconą formę stanowiska metafizycznego - wyboru (i akceptacji) świata panowania i posłuszeństwa.

Jest jeszcze jeden sposób wyjaśnienia niezrozumiałego (albo zrozumiałego jedynie w kategoriach psychologicznych) utożsamienia prawa ze złem cielesności. To przede wszystkim założenie (tkwiące implicite w antycielesnych filipikach Pawła) o immanentnym złu cielesności, zawarte $\mathrm{w}$ jednostronnym (podobnie jak jednostronne jest pawłowe rozumienie ducha) jej rozumieniu. Pozostawmy tym razem na boku samo prawo ${ }^{76}$ : to

76 Chociaż Wyszesławcew ani na chwilę go na boku nie pozostawia. Na stronie 112 przytacza bajkę rosyjską, ilustrująca, ,automatyczny” odruch łamania prawa: bohater bajki ujrzał czarny kamień z napisem, mówiącym, że kto przezeń przeskoczy, złamie kark. Bohater przeskoczył i zginął. Wyszesławcew, który skądinąd dobrze rozumie pochodzenie prawa od umowy, a nawet jakoś uniwersalizuje to pochodzenie, tu, podobnie jak w rozważaniach o Pawle, całkowicie ignoruje fakt, że „,prawo”, zakazujące skakania, jest tu arbitralne i zupełnie anonimowe jest jego źródło, i że ryzyko, w tym również ryzyko śmierci, jest wpisane w próby przekształcenia prawa jako arbitralnej woli silniejszego w prawo jako formę umowy. Przytoczona przez Wyszesławcewa bajka jest tylko uproszczoną i pozbawioną dalszego ciagu wersją bajki biblijnej, w której ukazano (w postaci boskich klątw) zarówno koszty operacji, jak i wytworze- 
cielesność wydaje się w ostateczności kluczem do zrozumienia „oryginalności” ,apostoła”.

Przypomnijmy kwestię ,ducha”. Duch jest dwoisty dwojako: po pierwsze - są dwa „duchy”: duch władzy i duch przymierza. Ale też każdy z tych dwóch duchów jest dwoisty, jest bowiem relacją między panującym i posłusznym (w przypadku pierwszego ducha) oraz relacją między wzajemnie uznającymi swoją równą kompetencję stronami (w przypadku ducha drugiego). Podobnie - choć niejako na innym piętrze - jest z ciałem, a raczej $-\mathrm{z}$ cielesnością. Pawłowe pojęcie cielesności, przejęte przez chrześcijaństwo, jest takie samo, jak pojęcie ducha: Paweł stoi na stanowisku, że duch jest jeden, i jest on absolutny. Jego władza jest nieograniczona, zwłaszcza w obrazie, w którym posłuszeństwo występuje w par excellence pozytywnej formie miłości, zaś nieposłuszeństwo w negatywnej formie grzechu, ale już nie w pozytywnej formie oporu i domagania się równego traktowania. To nierelacyjne rozumienie ducha („miłość” $i$ „łaska” zacierają relacyjny charakter ducha władzy), przeniesione na kwestię cielesności, daje następujące rezultaty: ciało, pozostawione samo sobie, nie stawia żadnych granic swoim pragnieniom, które, niczym nie limitowane, popadają w grzech, czyli skrajnie przedmiotowe traktowanie wszystkiego, co jest poza ciałem, w tym innego ciała, a często także własnego ciała. Gdyby jednak Paweł zechciał pojąć cielesność nie jako pojedyncze ciało (w tym jego własne „grzeszne” ciało), ale jako relacje między ciałami, gdyby się przestał bać re 1 a c j i ciał, ujrzałby wówczas, że w tej relacji, podobnie zreszta jak w re 1 a c j i duchowej, tkwi nie konieczność wprawdzie (i bardzo dobrze, tu gdzieś bowiem również sytuuje się wolność), ale poten c ja 1 wzajemnego ograniczania się ciał7 ${ }^{77}$, po-

nie nowego paradygmatu. Tak jak bajka Wyszesławcewa jest tylko połową bajki biblijnej, tak i Paweł z bajki biblijnej wziął tylko połowę, a po nim połowę tylko - dla uzasadnienia swojego partykularnego stanowiska - bierze chrześcijaństwo.

77 Podobnie jak w relacji duchowej tkwi potencjał wzajemnego ograniczania obustronnego dążenia do panowania. Warto tu odnotować, że fascynacja wielu, zwłaszcza religijnych, etyków formułą Dostojewskiego: „Jeśli Boga nie ma, wszystko wolno”, wynika z bezkrytycznego podejścia do nierelacyjnego stanowiska pisarza. Tymczasem zestawienie stanowiska relacyjnego (podmiot, któremu się ewentualnie wydaje, że „wszystko wolno", plus inny podmiot) i stanowiska nierelacyjnego (podmiot i jego nieokiełznane pragnienia) pokazuje, że o ile w drugim przypadku rzeczywiście jedynym czynnikiem limitującym pragnienia jest czynnik wobec podmiotu zewnętrzny, czyli władza, której kulminacyjnym punktem jest Bóg, o tyle w pierwszym możliwość ograniczenia podmiotowych aspiracji do totalnej dominacji nad nie-ja wpisana jest 
tencjał wzajemnego uznania ich równego statusu. I jeśli nawet ten potencjał nie może się do końca zrealizować bez udziału ducha, to nie musi to być duch władzy, więcej nawet - to n i e m o ż e być duch władzy (w tym władzy jednego ciała nad drugim), ale duch przymierza, duch porozumienia. A więc to duch przymierza, duch umowy jest w stanie stanąć na drodze ,grzechu”, czyli pragnienia ciała, nie liczącego się z innym ciałem i jego pragnieniami. Ale to oznacza, że w ostatecznym rachunku to władza, czyli wymuszanie posłuszeństwa, jest „grzechem” z punktu widzenia filozofii i etyki umowy, podobnie jak z punktu widzenia etyki posłuszeństwa grzechem (grzechem ,pychy”) jest domaganie się równego traktowania, czy to w relacji duchów, czy w relacji cial ${ }^{78}$. Tego nie rozumie lub nie chce rozumieć Paweł; lęk przed relacją ciał nie mógł nie zaowocować lękiem przed nieokiełznanymi siłami ciała ${ }^{79}$.

To nie jest filozofia, która mogłaby być zaakceptowana przez Pawła i jego wyznawców, jej przyjęcie oznaczałoby bowiem odwrócenie relacji między „najważniejszymi przykazaniami” i uznanie, że ciała i „dusze” mają pełne prawo negocjowania warunków relacji między nimi i że nie istnieje żaden taki „Duch”, oprócz ducha porozumienia, któremu przysługiwałoby „naturalne”, „boskie” prawo władzy nad ciałami i duchami tych ciał. Wyszesławcew, mimo iż otarł się o liberalną szkołę prawa, nie chce nieść ciężaru odwróconych przykazań ${ }^{80}$, podobnie jak nie chcą go

w samą relację, i dlatego w tym wypadku „hipoteza Boga” (Laplace) jest nie tylko zbędna, ale i myląca. Wniosek: teza Dostojewskiego nie jest ,prawdą absolutną”, lecz jedynie konsekwencją wyboru zasady podstawowej, jaką jest panowanie i posłuszeństwo, i konsekwencją przemilczenia tego faktu, że jest to wybór. Mówiąc prościej, jest to teza ideologiczna.

78 Dlatego oficjalna interpretacja Biblii uporczywie nazywa grzechem nieposłuszeństwa domaganie się przez człowieka uznania, że nie tylko Bóg potrafi odróżnić dobro od zła.

79 „A ja jestem cielesny, zaprzedany w niewolę grzechu” (Rz 7, 14). ,...we mnie, to jest w moim ciele, nie mieszka dobro" $(\mathrm{Rz} 7,18)$. Paweł boi się szukać dobra obok (w relacji z innym ciałem), wiemy bowiem skądinąd, że znalezienie go tam nie jest gwarantowane, tym bardziej, że procedura wzajemnego wymagania i wspólnego definiowania jest kłopotliwa - łatwiej jest nie stawiać wymagań, poddać się źródłu uznanemu za autorytatywne i arbitralnie narzuconą przezeń definicję dobra zaakceptować. I jeszcze doznać ulgi.

${ }^{80}$ Odwrócenie nie oznacza tu zwykłej zamiany miejscami „przykazania największego” („Będziesz miłował Pana Boga...”) i „drugiego podobnego do niego” (,będziesz miłował swego bliźniego jak siebie samego") (Mt 22, 37-39), ale przekształcenie go w „przykazanie” usytuowane w odmiennym kontekście aksjolo- 
nieść inni rosyjscy przedstawiciele filozofii religijnej, mimo poszukiwań na obszarze bliskiej archetypowi przymierza idei bogoczłowieczeństwa ${ }^{81}$. I nawet w swoich próbach zdefiniowania wolności pozostają ostatecznie wierni Pawłowi ${ }^{82}$.

Również Wyszesławcew, pomimo niepokoju o los moralności, pozostaje wierny.

\section{III.}

„Ku wolności wyswobodził was Chrystus" ${ }$, .

„Wy zatem, bracia, powołani zostaliście do wolności. Tylko nie [bierzcie] tej wolności jako zachęty do [hołdowania] ciału, wręcz przeciwnie, miłością ożywieni służcie sobie wzajemnie” ${ }^{\text {, }}$. „Bo całe prawo wypełnia się w tym jednym nakazie: Będziesz miłował bliźniego swego jak siebie samego" ${ }^{\prime \prime 5}$.

To co wyższe, „duch”, zasada, „wartość” musi mieć swoją formę, tylko z pomocą formy może osiągnąć kształt bytu, tylko z pomocą formy może stać się czymś uchwytnym, czymś intersubiektywnie czynnym, czymś komunikacyjnie funkcjonalnym. Odrzucenie prawa, i to nie tylko „żydowskiego”, ale prawa jako takiego (oskarżonego przy okazji o wszystko,

gicznym. Np.: „Nie będę stawiać żadnego boga ani żadnego ustroju politycznego ponad umowny, demokratyczny porządek konstytucyjny, a każdego człowieka będę uważać za kompetentnego w rozstrzyganiu kwestii publicznych, dla siebie domagając się takiego samego uznania”. W. Paradowska, R. Paradowski, W sprawie ,, dekalogu” etyki politycznej liberalnej demokracji, „Środkowoeuropejskie Studia Polityczne" 2006, nr 2. Pozbawiona absolutnego statusu relacja posłuszeństwa wobec wyższego szczebla hierarchii jest $\mathrm{w}$ tym kontekście aksjologicznym ujęta w ramę kontraktualną.

${ }^{81}$ Nie w jej kształcie ortodoksyjnym, mówiącym o „Synu Bożym”, będącym jednocześnie bogiem i człowiekiem, ale tam, gdzie jest mowa o relacji Boga i człowieka, która, przynajmniej zgodnie z Biblią, może, ale nie musi być hierarchiczna.

${ }^{82}$ Nawet Mikołaj Bierdiajew, który wahał się między koncepcją wolności poprzedzającej Boga (która zreszta, może wbrew intencji filozofa, samego Boga relatywizuje) a stanowiskiem ortodoksyjnie chrześcijańskim. Zob. R. Paradowski, Wolność jako wierność. Bierdiajew i Stiepun o wolności, w: Emigracja rosyjska. Losy i idee, red. R. Backer, Z. Karpus, Łódź 2002.
${ }^{83} \mathrm{Ga} 5,1$.
${ }^{84}$ Ga $5,13$.
${ }^{85} \mathrm{Ga} \mathrm{5,} 14$. 
co najgorsze, czyli o prowokowanie zła ${ }^{86}$ ) sugeruje, że chodzi o usunięcie wszelkiego zapośredniczenia, a więc wszelkiej formy, o bezpośredni kontakt człowieka z ,absolutem”. Z drugiej jednak strony, wskazanie na kościół świadczy o tym, że to co wyższe nie jest (może nie być) osiągalne bezpośrednio, cokolwiek by to miało oznaczać (intuicję, uczucie, ,wgląd”, kontemplację oblicza Boga itd., itp.), lecz za pośrednictwem „wspólnoty”, we wspólnocie, w określony sposób zorganizowanej.

Wydaje się zresztą, że jest to prawidłowość ogólniejsza, a nie tylko związana z odrzucanym prawem, tym bardziej, że, jak wiemy, zostało ono odrzucone, zgodnie z przekonaniem Wyszesławcewa, z powodu zasadniczej skazy (zasygnalizowanej tylko przez Pawła poprzez odwrócenie znaczenia pojęcia przymierza), skazy, wynikającej wprost z jego istoty, jaka, wedle przytoczonego wyżej jednoznacznego stwierdzenia filozofa, jest pochodzenie prawa od umowy społecznej. Prawo zostaje zatem odrzucone, bo nie jest rzekomo czymś właściwym oparcie relacji z absolutem (z Bogiem, z „duchem”, z wartościami podstawowymi) o zasadę kontraktualną. Ale także wolność, która jakoś się wiąże zarówno z relacją jednostki z absolutem, jak i jego formą, nie może mieć nic wspólnego z umową. Takie przekonanie Wyszesławcewa co do istoty wolności (na razie tylko co do tego, czym ona ewentualnie n i e j e s t) można, jak się wydaje, w pełni zasadnie założyć.

Dedukując z ogólnej deklaracji Wyszesławcewa o jego przynależności do chrześcijańskiej formacji umysłowej (filozoficznej, religijnej, światopoglądowej) można by również mniemać, że wolność (by o tyle przynajmniej dopełnić jej „negatywną” definicję) nie jest również absolutem. Jest ona jakoś z absolutem związana (,gdzie Duch Pański, tam wolność" ${ }^{87}$ ), ale to Bóg jest absolutem, wolność zaś może ewentualnie przysługiwać jemu, w każdym razie wolność pojęta jako możność robienia absolutnie wszystkiego, czego „dusza zapragnie”88 albo może przysługiwać człowiekowi, o ile się odpowiednio z „Duchem Pańskim” skoreluje, o ile

86 Wyszesławcew nie decyduje się ostatecznie na radykalizm w tej kwestii, a jednocześnie swoją interpretacją stara się osłabić wymowę radykalizmu Pawła, rozróżniając ,scholastycznie” przyczynę i powód. Zob. Wyszesławcew, op. cit., s. 56.

872 Kor 3, 17.

88 Warto zwrócić uwagę, że akurat Bogu przypisuje się ten rodzaj wolności, której - jako prymitywnej - nie chce się przypisywać człowiekowi (z tą różnicą, że w wypadku człowieka „samowola” jest usytuowana w ,ciele”, w wypadku Boga natomiast - w żadnej konkretnej substancji; natomiast w jednym i drugim przypadku skierowana jest - przynajmniej potencjalnie - na świat jako całość, traktowany przez oba podmioty, tu: podmioty panowania, jak swoje przedmioty). 
będzie postępować zgodnie z nakazami tego „ducha”. Wolność sytuowałaby się więc gdzieś poniżej absolutu, chociaż - nie dużo niżej.

Tu jednak czeka nas niespodzianka, jakkolwiek, ostatecznie - niezbyt wielka. Bo wprawdzie jest w całokształcie poglądów Wyszesławcewa na wolność pewien komponent niechrześcijański, nie on jednak stanowi o charakterze jego stanowiska; ten komponent wydaje się sztucznie doczepiony do systemu, na system nie wpływa, chociaż nadaje mu do pewnego stopnia charakter eklektyczny. Oto bowiem wolność występuje również u Wyszesławcewa $\mathrm{w}$ roli absolutu ${ }^{89}$.

Jednym z fundamentów chrześcijańskiej doktryny jest, jak wiadomo, idea wolnej woli, czy, inaczej mówiąc, idea wyboru. Przynajmniej więc w tym znaczeniu - jak się jednak okazuje, nie wystarczającym dla uznania metafizycznego statusu wolności - wolność w tej doktrynie występuje.

Przyjmijmy wstępnie, że wybór między jakimś A i jakimś $\mathrm{B}$ jest podstawową (metafizyczną) prerogatywą jednostki. Warto zaznaczyć, że owe A i B nie są tak zupełnie ,jakieś”, zważywszy na to, że jako szczególnie ważne (na przykład jako „dobro" i jako „zło" ",0) istnieją (skądinąd do wyboru) tylko one, a już nie żadne $\mathrm{C}$ czy D. Chodzi więc nie o wybór czegokolwiek z jakiejś dość szerokiej gamy możliwości, ale o wybór naprawdę fundamentalny. Ale czy rzeczywiście fundamentalny - w każdym razie w jego chrześcijańskiej wersji?

Zdawać by się mogło, że tak, przynajmniej w wersji Wyszesławcewa. „Między nimi (między naszymi A i B, chwilowo jeszcze nieokreślonymi

89 To nie jedyny taki przypadek u Wyszesławcewa. Gdyby nie odrzucenie prawa chociaż przecież nie absolutne, bo przynajmniej prawo moralne (mimo iż stara się nienormatywną etykę ukonstytuować) filozof odrzuca z pewnym ociąganiem, więc może i nie odrzuca do końca - a więc gdyby nie odrzucenie prawa, można by uznać, że umowa społeczna ma przynajmniej c oś w s póln e g o z absolutem, tak jednoznacznie wiąże on istotę prawa $\mathrm{z}$ umową społeczną. Odwracając nieco rozumowanie można by powiedzieć (gdyby nie odrzucać, nie przekreślać prawa), że, jako forma absolutu (a w tej właśnie roli zostało prawo przez Pawła i przez Wyszesławcewa zakwestionowane), jest prawo formą umowy społecznej, choćby i formą „przymierza”, a sama umowa - absolutem. Ale tu już nie ma miejsca na Boga, przynajmniej takiego, który byłby czym innym i czymś więcej niż stroną takiej umowy. Przemianowanie przez Pawła przymierza na obietnicę i łaskę i zastąpienie prawa (między innymi przez Wyszesławcewa) przez kościół, i, szerzej, przez wszelkiego pasterza, przez charyzmatycznego przywódcę - oto na czym polega przeformułowanie przesłania starotestamentowego i przekształcenie go w przesłanie chrześcijańskie.

90 W cudzysłowie, bo tu się kryje chrześcijańska pułapka, w którą Wyszesławcew - i nie on jeden - wpada. 
- R.P.) decyduje ostatnia i najwyższa (vysshaja) instancja wolności, stojąca nad wszystkimi świadomymi argumentami i opiniami; wolność, niczym nieugruntowana, bo wznosząca się nad wszelkimi racjonalnymi uzasadnieniami"91. Przybliżyć z pomocą słów absolut - a najwyraźniej w tej roli występuje tu wolność (nic „nad”, nic „pod”, a wszystko z niej) - w jak najmniejszym stopniu ujmując mu jego statusu przez względność wszelkich słów, nie jest łatwo. Trzeba jednak przyznać, że filozofowi się to, o ile to w ogóle możliwe ${ }^{92}$, udaje; mówi on jeszcze o „ostatniej głębi”, albo, jak Jakub Boehme i Bierdiajew, o „ungrund”, o „,irracjonalnej «otchłani»" "93.

Takie rozumienie wolności może być uznane za metafizyczne. I może nie tyle dlatego, że nic nie ma „pod nią",94; raczej dlatego, że nic nie ma „nad nią”. O takiej wolności zdaje się mówić Wyszesławcew, ale brzmi to u niego tylko jako echo czegoś, jakiejś innej, niechrześcijańskiej metafizyki, albo jako jej możliwość. Wyszesławcew, prędzej jeszcze niż Bierdiajew, który, zanim ${ }^{95}$ jako filozof „nawrócił się” na chrześcijaństwo, kwestię metafizycznej wolności drążył dość uporczywie, już w drugim zdaniu akapitu (w pierwszym cytowanym ustępie), a nawet w drugiej części zdania (w ustępie drugim) przekreśla absolutny, metafizyczny charakter wolności. Podział wolności na „niższą” - samowolę, i „wyższą”, „wysublimowaną" (wybór dobra), a także (choć w mniejszym stopniu) na „negatywną” i ,pozytywną” powoduje, że deklaracja absolutnie pierwot-

91 Wyszesławcew, op. cit., s. 71.

92 Por. „nie będziesz wzywał imienia Pana, Boga twego, nadaremnie”. „Bóg” albo „Jahwe”, jest równie dobrym, jak każde inne, oznaczeniem absolutu, bowiem nie znaczy nic, co najwyżej o z n a c z a; znaczenie można bezkarne przypisać tylko formie, np. „Panu” albo ,przymierzu” - nie wiadomo, co to takiego „Bóg”, ale wiadomo, co to „pan” i co to takiego ,przymierze”. Pozostaje to jakoś ekstrapolować na absolut, i tym się będzie zajmować do końca czasów filozofia.

93 Ibidem, s. 113.

94 Można sobie wyobrazić coś, co, będąc „pod” wolnością albo ją jakoś poprzedzając, nie ujmuje jej absolutu (nie powoduje, że przestaje być ona wolnością); z całą pewnością jednak istnienie czegoś nad nią pozbawi ją własnej istoty.

95 Słowo „zanim” może sugerować jakieś następstwo czasowe, podczas gdy dwa odmienne poglądy na wolność, chrześcijański i filozoficzny, występują u niego w sposób względnie niezależny, o czym świadczy ostatnia książka tego filozofa, zatytułowana Opyt eschatołogiceskoj mietafiziki. Zob. W. Paradowska, R. Paradowski, Bierdiajewa filozofia wolności, w: M. Bierdiajew, Zarys metafizyki eschatologicznej, Kęty 2004. 
nego charakteru wolności pozostaje deklaracją bez pokrycia ${ }^{96}$. I to nawet nie dlatego, a może - nie przede wszystkim dlatego, że ponad wolnością okazuje się „Bóg” (bo i tak nie wiadomo, co to takiego, a wiadomo przynajmniej, że może to być zarówno ,pan”, jak i „przymierze”), ale dlatego, że Wyszesławcew, wbrew pozorom, wprowadza - i sytuuje ponad wolnością - instancję, która, zanim jeszcze wolność „zadziała”, wstępnie waloryzuje pozostające jednostce do wyboru A i B, powodując, że wolność przestaje być sobą, bo niczego już nie konstytuuje (oprócz statystycznego rozkładu głosów na A i na B), nie konstytuuje samych A i B, ma je bowiem już (zanim przystąpi do „wolnego” wyboru) wstępnie ukonstytuowane. Innymi słowy, istnieje jakaś instancja, która przygotowała pozornie alternatywną ofertę, bo ofertę ze wskazaniem. Jestem wolny, jeśli wybiorę to, co mi ta instancja wskaże jako warte wyboru, co sama ta instancja definiuje jako warte wyboru. To taki rodzaj plebiscytu, gdzie pytanie sformułowane jest w taki sposób, aby wymusić określoną opcję. Albo jeszcze inaczej: wybierasz nie między A i B, waloryzując je tym samym (jedno z nich uznając za „dobre”, drugie za „złe”), ale między A, jako dobre zdefiniowanym przez ową wyższą instancję, i $\mathrm{B}$, zdefiniowanym przez nią jako złe. Ponieważ instancja jest wyższa (nad nią już rzeczywiście „nic nie ma”) to i definicje są obowiązujące, są absolutne ${ }^{97}$. "Wolna wola” więc, a także, wbrew wstępnym deklaracjom, „otchłań”, „najwyższa instancja wolności” itd. to taka wolność okrojona do rozmiarów... posłuszeństwa. Jestem wolny, jeśli jestem posłuszny definiującemu, jeśli jestem posłuszny j e g o definicji, któż bowiem dobrowolnie wybierze zło, zwłaszcza jeśli opanuje popędy ciała i „da się prowadzić duchowi”. Temu samemu duchowi, który definiuje A jako dobro, a B jako zło i tak uformowane „dobro" i ,zło” „wolnej woli” do wyboru podsuwa. Nie wiadomo, co to jest „Bóg”, ale bardzo dobrze wiadomo, co to jest posłuszeństwo. Wolność występuje w tej metafizyce jako pseudonim posłuszeństwa. I na nic się nie zdają zapewnienia, że nie chodzi o to, by uczynić z człowieka „automat dobra”. Wyszesławcew przyznaje, że „Bóg chce” (chociaż zarazem „nie chce”) „byśmy byli Jego rabami”, i z tego żądania nie rezygnuje,

96 Stwierdzenie, że wolność nie ma u Wyszesławcewa absolutnie pierwotnego charakteru, nie powinno być traktowane jako zarzut; jeśli już mówić o zarzutach, to będą one raczej dotyczyć określenia samego zakresu wolności.

97 Ma rację Grzegorz Przebinda, kiedy sugeruje (tylko sugeruje), że nie musi to prowadzić do prześladowania heretyków, cóż, kiedy przeważnie prowadziło, a tego sugestia Przebindy już nie zawiera. Por. G. Przebinda, Od Czaadajewa do Bierdiajewa. Spór o Boga i człowieka w myśli rosyjskiej (1832-1922), Kraków 1998, s. 441. 
chce jednak, byśmy byli nimi z miłości, co ma rzekomo wystarczać dla uniknięcia wspomnianego automatyzmu ${ }^{98}$. I jak by mogło wystarczyć dla uniknięcia autorytaryzmu.

Wyszesławcew, zresztą nie on jeden, przyjmuje za punkt wyjścia wolność jako samowolę i oczywiście określa ją (nic bardziej banalnego z filozoficznego punktu widzenia) jako „niższą,"99. Można by nawet pójść dalej i powiedzieć, że nie jest ona (jako odniesiona tylko do własnych popędów) w ogóle wolnością, ale właśnie - samowolą, niewolą u natury, egoizmem, swoistym ontycznym solipsyzmem. Jednak ,samowola” jest filozofowi potrzebna, coś bowiem musi ulec sublimacji (a sublimacja właśnie ma być drogą od niższej do wyższej wolności), aby mógł nastąpić wybór dobra i tym samym właściwa wolność mogła się ukonstytuować.

Sama idea sublimacji o niczym jeszcze nie przesądza, łatwo bowiem przyjąć, że popędy jakoś wysublimowane przekształcą się w coś bardziej subtelnego niż one same. Ważny jest raczej mechanizm owej sublimacji. Jest to mechanizm chronicznie ustrukturowany hierarchicznie, podobnie jak hierarchia kryje się za „wyborem dobra”. Zresztą i metafory, do których się Wyszesławcew odwołuje, zakładają (albo projektują) hierarchię, a przede wszystkim metafora „dążenia wzwyż”, tam, gdzie usytuowany jest wzór, model, gdzie czeka gotowa definicja dobra, na którą należy się orientować, aby popędy wysublimować.

„Religia zasadza się na aksjomacie zależności od Istoty Absolutnej, na postrzeganiu siebie jako istoty względnej, skończonej i stworzonej (tvarnoj)" ${ }^{\text {"100 }}$. Już sama radykalna dystrybucja absolutu (wszystko po stronie „Istoty Absolutnej”, nic (względność, skończoność itd.) po stronie człowieka $^{101}$ ) stawia kwestię wolności pod dużym znakiem zapytania. Deklarowana zależność, nie będąca w żadnym wypadku współzależnością ${ }^{102}$, te wątpliwości dodatkowo potęguje. Potęguje je zresztą również

98 Zob. Wyszesławcew, Wiecnoje..., s. 675.

99 Chociaż nie może nie niepokoić, że również boska wszechmoc mieści się w opisie samowoli. Wprawdzie samowola jest również określana jako wybór zła, a Bóg, jak wiadomo, zła wybrać nie może (jakkolwiek, jako „wszechmocny”, powinien móc), ale tę sprzeczność łatwo usunąć przez stwierdzenie, że wszystko, co robi Bóg, jest dobre.

100 Wyszesławcew, op. cit., s. 103.

101 W sprawie struktury Absolutu zob. R. Paradowski, Afirmacja i wiara a wybór metafizyczny. Bóg w strukturze absolutu, „Przegląd Religioznawczy”2007, nr 4.

102 Zależność jest zawsze (każda relacja jest zależnością), ale nie zawsze jest to zależność jednostronna: wzajemne uznanie podmiotowości (miłowanie bliźniego, przymierze itp.) to też zależność, tyle, że wzajemna. Nawiasem mówiąc, zależność jest 
Wyszesławcewa argumentacja na rzecz budowania sublimacji (a pośrednio - wolności) przez sugestię. Twierdzi Wyszesławcew, że mechanizmem napędowym sublimacji jest sugestia, a dokładnie - sugestia religijna. Filozof zgłasza obawę, że sugestia może czynić niepotrzebną świadomą wolną wolę, że człowiek staje się tu ,pasywnym medium” (tymże ,automatem dobra"), a wolny jest tylko ten, który sugeruje, a nie ten, który sugestii jest poddany. Jeśli jednak weźmiemy pod uwagę (a Wyszesławcew bierze), że sugestia jest zawsze autosugestią, to wolność „odzyskuje swoje suwerenne prawa".

Pozostawmy na boku psychologiczno-psychiatryczny problem statusu sugestii i przyjmijmy za Wyszesławcewem, że o żadnej pasywności (przynajmniej przyzwolenie jest tu warunkiem koniecznym) nie może być mowy, tym bardziej, że w ostatecznym rachunku autosugestia jako mechanizm sublimacji związana jest według naszego autora $\mathrm{z}$ nad wyraz istotną dla wolności kwestią wyboru: pozwala postawić kwestię ,przezwyciężenia przypadkowych i niecelowych autosugestii z pomocą autosugestii wybranych i celowych"103. Wprawdzie w tym kontekście nie ma mowy o gotowym wzorze, który sobie ,autonomicznie” narzucamy, $\mathrm{w}$ istocie jednak mamy tu do czynienia ze znanym już, „danym”104, dobrem i złem, przesądzającym o jednowymiarowym charakterze sublimacji, o tym, że droga od egoizmu i cielesności („,płoti”) do tego co wyższe jest jedna. Tym bardziej, że ,prawo nie sublimuje" ${ }^{105}$, a więc nie sublimuje

jakoś wzajemna zawsze, stąd negowanie owej wzajemności może być słusznie podejrzane o ideologiczną stronniczość.

103 Wyszesławcew, op. cit., s. 106.

104 „Aby wybierać, rozstrzygać, orientować się, wolna wola winna mieć przed sobą porządek wartości, który jest jej dany i w którym ona niczego zmienić nie może”. „Autonomia jednostki wymaga autonomii zasady". Wyszesławcew, Wiecnoje..., op. cit., s. 671 .

105 Wyszesławcew, Wiecnoje..., op. cit., s. 659. ,...«prawo» nie sublimuje, to znaczy nie ciagnnie w górę, nie przeobraża podświadomości, nie sublimuje dlatego, że wywołuje irracjonalny opór podświadomych impulsów, czyli wywołuje nieświadomy opór ludzkiej woli”. Dysfunkcjonalność prawa względem sublimacji zawisła więc całkowicie od uniwersalnej (a nie tylko ograniczonej, związanej z niedojrzałością osobowości, oraz z zewnętrznym wobec jednostki źródłem prawa) prawdziwości tezy o prawie (zakazie i nakazie) jako czynniku rodzącym bunt, sprzeciw, opór. Można by się nawet umówić, że sublimacją nazywać będziemy ruch w górę w ramach relacji posłuszeństwa (samoograniczenie się posłusznego wedle wzoru narzuconego przez panującego), a ruch w górę w ramach relacji podmiot-podmiot określimy jakoś inaczej, rzecz w tym jednak, że Wyszesławcew wcale tego nie chce. 
umowa, porozumienie, przymierze, nie sublimują wzajemne wymagania (na przykład jak w przykazaniu miłowania bliźniego jak siebie samego), nie sublimują wzajemne wymagania w sferze cielesności. Nie sublimuje więc relacja $\mathrm{z}$ innym podmiotem jako podmiotem. „Jeśli niczego i nikogo nie ma nade mną, wówczas sublimacja jest niemożliwa"106. Sublimuje ostatecznie tylko posłuszeństwo. Z wnioskiem tym Wyszesławcew - nie wiedzieć czemu - nie chce się jednak zgodzić: ,Jeśli nade mną jest absolutna władza, imperatyw, prawo - wówczas sublimacja też jest niemożliwa...". Wyjście $\mathrm{z}$ tej niewygodnej sytuacji znajduje filozof w relacji „Bogo-Synostwa”: „syn odpowiada na... «wezwanie»” (z góry) „swobodną miłością”, i zarazem nie może na nią nie odpowiedzieć, skoro „na rozkaz tyrana odpowiedziałby odmową posłuszeństwa", a tym, który „wzywa” nie jest przecież „tyran”, lecz „ojciec”. Ostatecznie więc, tak czy owak, chodzi jednak o posłuszeństwo, chociaż nie o ,posłuszeństwo ze strachu”, lecz o ,posłuszeństwo z miłości”107. Jeśli nawet nie „gołe” posłuszeństwo jest w chrześcijaństwie i w chrześcijańsko inspirowanej filozofii synonimem wolności, to jest nim w każdym razie ,posłuszeństwo z miłości”. Na pewno posłuszeństwo ze strachu i posłuszeństwo z miłości to z psychologicznego punktu widzenia nie to samo, ale czy również z metafizycznego? Tym bardziej, że tylko miłość władzy, „miłość polityczna”108, ale już nie „miłowanie bliźniego jak siebie samego”, łączy się harmonijnie $\mathrm{z}$ posłuszeństwem.

Należy zaznaczyć, że orientowanie się na wzór, na model, a nawet na autorytet nie jest samo w sobie czymś złym, co więcej, w określonym kontekście (na przykład w kontekście pedagogicznym) może być nawet czymś zdecydowanie dobrym. Tyle że kontekst pedagogiczny, czy nawet szerzej - społeczny, to jednak coś innego niż kontekst metafizyczny; w określonym kontekście społecznym dobrem (absolutem) może być A, w innym zaś - B. Metafizyka nie może jednak polegać na absolutyzowaniu A i definiowaniu B jako prostego przeciwieństwa A (jako „zła”), ale na zdefiniowaniu zarówno A, jak i B jako wartości do wyboru, bez uciekania, oczywiście, od samego wyboru. „Wyboru niczym nie można uzasadnić

106 Wyszesławcew, Wiecnoje..., op. cit., s. 675.

107 A więc ostatecznie sublimacja będzie dla Wyszesławcewa tylko ruchem w górę w ramach relacji hierarchicznej. Nie będzie więc, w szczególności, sublimacją r e 1 a c j i cielesnej, lecz ograniczeniem popędów przez - i ze względu na-dominujący podmiot.

108 „Ot Otca, ot ierarchiceski wyssego, ishodit prizyw”. Wyszesławcew, Wiecnoje..., op. cit., s. 675. 
już choćby dlatego, że «uzasadnienie» istnieje tylko dla kogoś, kto już dokonał wyboru..."109. Metafizyczna intuicja Wyszesławcewa, uwikłana skądinąd we wstępne chrześcijańskie rozstrzygnięcie, prowadzi go zarazem ku wewnętrznej złożoności metafizyki: konstatacji koniecznego wyboru między A i B (chociaż tu już z góry jako dobro i zło zdefiniowanych) oraz konieczności wyboru, dokonywanego przez samego metafizyka. To, co można tu Wyszesławcewowi jako metafizykowi zarzucić to to, że s w ó j wybór utożsamia z w y b o r e m m e ta fi z y c zn y m w o góle. I dlatego jego własny wybór ostatecznie gdzieś znika, utożsamiony z wyborem, dokonanym za niego „wyżej”. I ostatecznie znika sam wybór (w każdym razie w swoim znaczeniu metafizycznym), skoro „wartość... jest zawsze dana"110, skoro powinność jest zawsze jednoznacznie skierowana - ku górze, ku władzy.

Tylko gwoli ilustracji wypada przytoczyć jeszcze określenia, użyte przez Wyszesławcewa na oznaczenie wartości podstawowych.

Stwierdzić trzeba od razu, że nie ma u Wyszesławcewa ,wartości podstawowych" (chyba, że zgodnie z duchem etyki jako nauki również ,wartość negatywną”, ,antywartość” nazywać będziemy wartością), jest tylko wartość (jedna wartość) i jej zaprzeczenie. Wolność „wybiera w ostatecznym rachunku między twórczością i burzeniem, między życiem i śmiercią, między «tak» i «nie»". Jest Eros sublimacji, czyli dążenia do Dobra, Eros miłości, i Eros „wypaczony”, Eros nienawiści, Eros degradacji, Eros upadku, Eros akceptujący i Eros profanujący. Jest plus i minus. I oba

109 Wyszesławcew, Etika..., op. cit., s. 71.

110 Ibidem, s. 75. To, że wartość jest dana, wynika również z Wyszesławcewa struktury sublimacji: „Sublimacja ma trzy ... szczeble:

1) Sublimacja afektów i dążeń, wyrastających z podświadomości, sublimacja Erosa.

2) Sublimacja wyboru, formująca te afekty.

3) Sublimacja ,powołania” (prizyva), for m u j ą c a wolność wyboru (podkr. RP)". (Wyszesławcew, s. 135).

Wolność, jednostronnie formowana z zewnątrz, nie jest, co oczywiste, wolnością. $\mathrm{Z}$ drugiej strony, kierowany duchem miłowania bliźniego, a nie duchem miłości jednostronnej i bezwarunkowej, mógłby Wyszesławcew uratować „wolność formowaną", formowaną wzajemnie przez bliźnich, którzy się wzajemnie ,powołują”. Mógłby, gdyby chciał. Jednostronne „powołanie” formuje wolność w jej własne przeciwieństwo, czyli w posłuszeństwo, gdy tymczasem wolność jako taka jest tożsama z wzajemnym powołaniem i odpowiedzią na owo powołanie. Wyszesławcew, i w ogóle chrześcijaństwo, chce wtłoczyć wolność w strukturę, odzwierciedloną w opowieści o zakazie spożywania owoców z drzewa poznania dobra i zła, podczas gdy tylko struktura przymierza daje się pojąć jako struktura wolności. 
- przy czym plus jako plus, minus jako minus, istnieją (są „dane”) jako takie przed wszelkim wyborem. Wybiera (definiuje) Bóg, „duch”, wybiera się (definiuje) gdzieś „wyżej”, a wolność „wybiera” już w swej pozytywności bądź negatywności określone coś, a więc tylko naśladuje wybór już przez kogo innego gdzie indziej dokonany. Jeśli przyjmiemy, że wolność nie tyle ,przysługuje” komuś (już to Bogu, już to człowiekowi), ale jest relacją między jakimś X i jakimś $\mathrm{Y}$, to u Wyszesławcewa jako chrześcijanina (i w tym zakresie, w jakim jest on, jako filozof, chrześcijaninem), jest to relacja między człowiekiem, który stara się dowiedzieć, czego chce od niego Bóg, i zgodnie z tym „wybierać” (akceptować lub odrzucać wolę Boga), i Bogiem, który określonego „wyboru” od człowieka oczekuje i gotów jest, zależnie od tego, co człowiek „wybierze”, nagradzać go lub karać. W tym kontekście „samowolą” będzie nie tylko orientacja człowieka na swoje „ciało”, a w istocie - na świat traktowany przezeń jak rezerwuar środków zaspokojenia pragnień, ale również, najwyraźniej, każda inna orientacja na ów świat, która nie spełnia kryteriów zarysowanej wyżej relacji człowieka z Bogiem ${ }^{111}$. W szczególności taka orientacja, która biorąc za punkt wyjścia odrzucaną przez Wyszesławcewa zasadę umowy sytuuje to co wyższe (i sam proces sublimacji) między ludźmi, niekoniecznie związanymi, a raczej - zupełnie nie związanymi relacją władzy.

111 Jeśli „całe prawo” wypełniałoby się w przykazaniu miłowania bliźniego (a jak wiadomo, nie „wypełnia się”, bo przykazanie to nie odnosi się do relacji z Bogiem i z pochodzącą od niego władza), nie można by było twierdzić, że wartości są dane (przez jedną stronę relacji do wiadomości i wykonania przez drugą stronę), bowiem to akurat przykazanie, jako jedyne, zakłada równość stron relacji między „bliźnimi”. Rzecz znamienna, że chociaż, zgodnie z dosłownym odczytaniem Pawła, to w tym przykazaniu wypełnia się „całe prawo”, to nie relacja bliźni-bliźni stanowi punkt wyjścia dla metafizyki Wyszesławcewa, ale (zapewne zgodnie z odczytaniem „głębszym”, odczytaniem intencji) raczej niezapośredniczona relacja z Bogiem jako najwyższą władzą. Nota bene „wypełnienie się prawa” w przykazaniu miłowania bliźniego jak siebie samego można rozumieć również w tym sensie, że prawo jest właściwe do regulowania stosunków między ludźmi, zaś w stosunkach z Bogiem i pochodzącą od niego władzą nie jest właściwe (tu właściwa jest łaska i nastawienie na łaskę); co więcej, ludźmi są tylko ci, z którymi nie jesteśmy w relacji panowania i posłuszeństwa; kto jest nośnikiem władzy, czy „człowiek”, czy „Bóg”, nie ma żadnego znaczenia, bo w relacji panowania i posłuszeństwa w ogóle nie występują „ludzie”, lecz panujący i poddani. Człowiekiem jestem tylko w relacji „miłowania”, czyli w relacji podmiotowo-podmiotowej, poza niąjestem tylko funkcją władzy. Funkcją władzy jestem więc w relacji z bogiem i pochodzącą od niego władzą. Nie wydaje się, by Paweł i Wyszesławcew zechcieli zaakceptować te konsekwencje. 
„Jeśli ...nikogo nie ma nade mną, sublimacja nie jest możliwa”, powiada Wyszesławcew, chociaż sam twierdził wcześniej coś zgoła odwrotnego $^{112}$. Gdyby chciał być bardziej precyzyjny, powinien powiedzieć, że bez spełnienia tego warunku („Jeśli nikogo nie ma nade mną"113) nie jest możliwa sublimacja w jej chrześcijańskim rozumieniu. Tak jak nie jest możliwe chrześcijańskie rozumienie wolności bez ograniczenia jej do wyboru między posłuszeństwem (choćby i „z miłości”) a nieposłuszeństwem „Istocie Absolutnej”, która kumuluje w sobie kosztem człowieka cały absolut, i której-odmiennie niż człowiekowi - przysługuje pierwszorzędny status metafizyczny.

\section{Summary}

According to Wyszesławcew, the starting point of any moral reflection that would be deserving of the name is the statement that is a philosophical transposition of the Apostle's words: evil emerges into the world accompanying law. The words should be understood quite literally - it is not that with law we develop the awareness of evil that we have already unconsciously committed. The point is that once established, the law prompts us to evil. Wyszesławcew's notion of law is very broad; he understands law as any ethical, customary, religious or legal norm, especially when it assumes the form of prohibition. Therefore, both the order of Moses and the ethics of the Stoics, Roman law and Kant's categorical imperative are ominous, demoralizing laws.

112 „Jeśli nade mnąjest władza absolutna, wówczas sublimacja nie jest możliwa”.

113 „Jeśli Boga nie ma, wszystko wolno”. 
